\title{
AGGURAGY INQUIRIES FOR ALL FELONY AND MISDEMEANOR PLEAS: VOLUNTARY PLEAS BUT INNOGENT DEFENDANTS?
}

\author{
John L. BarkaI $\dagger$ \\ I. INTRODUCTION
}

Despite the popular myth of American jurisprudence that a defendant's guilt or innocence is determined by a jury of his peers, conviction by a plea of guilty or nolo contendere is a long-standing feature of the American criminal justice system. ${ }^{1}$ Although no national statistics are available, it is estimated that between eightyfive to ninety-five percent of all criminal convictions result from guilty pleas. ${ }^{2}$ A defendant's guilty plea relieves the government of its obligation to produce evidence proving the defendant's guilt beyond a reasonable doubt. It does not, however, strip a defendant of all the protections against unfair or improper methods that might

$\uparrow$ Associate Professor of Law, Wayne State University Law School. B.B.A. 1967, M.B.A. 1968, J.D. 1971, University of Michigan. The author wishes to thank Irwin Stotzky of the University of Miami School of Law who made helpful comments on an earlier draft, and Anthony Chase and Mark Granzotto, third-year students at the Wayne Law School, for their valuable assistance in the preparation of this Article. The author wishes to state that, as a compromise between the sometimes competing stylistic goals of clarity and the absence of sexism, the masculine gender will be used herein for all personal pronouns although the feminine gender is equally appropriate.

I The practice of plea bargaining derives from attempts to mitigate the harsh punishments of 17th century English courts. Dash, Cracks in the Foundation of Criminal Justice, 46 IL工. L. REv. 385, 396 (1951); Note, Plea Bargaining-Justice Off the Record, 9 WashBURN L.J. 430, 432 (1970). "Plea bargains have accompanied the whole history of [American] criminal jurisprudence." Bryan v. United States, 492 F.2d 775, 780 (5th Cir.), cert. denied, 419 U.S. 1079 (1974); see Comment, The Plea Bargain in Historical Perspective, 23 Buffalo L. Rev. 499 (1974) and cases cited therein. For the first treatment of the subject in the Supreme Court, see Kercheval v. United States, 274 U.S. 220 (1927).

2 See ABA Project on Mintmum Standards for Criminat Justice, Standards Relating to Pleas of Guntty 1-2 (App. Draft 1968) [hereinafter cited as ABA Plea Standards]; D. Newman, Conviction: The Determination of Guint or Innocence Without Trual 3 (1966); The Presment's Commusston on Law Enforcement and Aominstration of Justice, Task force Report: The Courts 9 (1967) [hereinafter cited as CourTs].

Because fewer and less accurate statistics are compiled on misdemeanors than on felonies, this Article must assume that people charged with misdemeanors plead at approximately the same rate as those charged with felonies. Support for this assumption is found in a study showing that the likelihood of a defendant pleading guilty increases as the seriousness of the crime decreases. H. KaIVEN \& H. ZEISEI, The AMErican JuRx 20 (1966). 
be employed against him in the plea process, just as a defendant who elects to stand trial is protected from the use of improper methods against him at trial. Voluntariness and understanding, for example, are well-established constitutional prerequisites to a valid guilty plea. ${ }^{3}$

As the courts accorded formal recognition to plea bargaining, ${ }^{4}$ increasing attention was focused on the institutional and personal pressures that induce defendants to plead guilty. Particular concern centered on the innocent defendant whose legal guilt might be sealed by a plea of guilty. This concern is reflected in rule 11 of the Federal Rules of Criminal Procedure ${ }^{5}$ and in numerous state cases and statutes ${ }^{6}$ requiring a trial judge, in certain situations, to establish a factual basis for a guilty plea before accepting it. Except under the federal standard, however, the accuracy inquiry is generally required only in felony cases. Defendants who plead

3 See, e.g., McCarthy v. United States, 394 U.S. 459 (1969).

4 See, e.g., Santobello v. New York, 404 U.S. 257 (1971), holding that "[t]he disposition of criminal charges by agreement between the prosecutor and the accused, sometimes loosely called 'plea bargaining;' is an essential component of the administration of justice." Id. 260.

5 "Determining Accuracy of Plea. Notwithstanding the acceptance of a plea of guilty, the court should not enter a judgment upon such plea without making such inquiry as shall satisfy it that there is a factual basis for the plea." FED. R. Cranr. P. 11(f). Notice, however, that the accuracy inquiry is only made for guilty pleas in the federal courts and does not apply to nolo contendere pleas.

6 Among those states currently employing some form of factual basis requirement are: Arizona, State v. Campbell, 107 Ariz. 348, 488 P.2d 968 (1971), Aruz. R. Crmar. P. 17.3; Arkansas, Byler v. State, 257 Ark. 15, 513 S.W.2d 801 (1974) (by implication); California, CAI. PENar CODE $\$ 1192.5$ (West Supp. 1977); Colorado, People v. White, 182 Colo. 417, 514 P.2d 69 (1973), Colo. Rev. Stat. \$16-7-207(2)(f) (1973); Connecticut, State v. Battle, 170 Conn. 469, 365 A.2d 1100 (1976); Delaware, Dex. Super. Cr. Crma. R. 11; Florida, Williams v. State, 316 So. 2d 267 (Fla. 1975), Fra. R. Crem. P. 3.170(j); Illinois, People v. Hudson, 7 IIl. App. 3d 800, 288 N.E.2d 533 (1972), Ir.. Sup. Cr. R. 402(c); Iowa, State v. Sisco, 169 N.W.2d 542 (Iowa 1969); Kansas, Widener v. State, 210 Kan. 234, 499 P.2d 1123 (1972), Kan. Stat. AnN. \$22-3210(4) (1974); Maine, Child v. State, 253 A.2d 691 (Me. 1969), cert. denied, 396 U.S. 1044 (1970); ME. R. Crna. P. 11(a); Michigan, People v. Nicholson, 395 Mich. 96, 235 N.W.2d 132 (1975), cert. denied, 97 S. Ct. 1142 (1977), Mrch. Gen. CT. R. 785.7(3); Minnesota, State v. Spann, 289 Minn. 497, 182 N.W.2d 873 (1970), MINN. R. CRMM. P. 15.01, 15.02; Nebraska, State v. LeGear, 187 Neb. 763, 193 N.W.2d 763 (1972); New Jersey, State v. Pugh, 117 N.J. Super. 26, 283 A.2d 537 (1971); New Mexico, N.M. STAT. ANN. § 41-23-21(h) (Supp. 1975); New York, People v. Serrano, 15 N.Y.2d 304, 206 N.E.2d 330, 258 N.Y.S.2d 386 (1965); North Carolina, N.C. GeN. STat. 15A-1022(c) (1975); North Dakota, State v. McKay, 234 N.W.2d 853 (N.D. 1975), N.D. R. Cram. P. II(e); Oregon, OR. Rev. STat. \$ 135.395 (1975-76); Pennsylvania, Commonwealth v. Nelson, 455 Pa. 461, 317 A.2d 228 (1974); South Carolina, State v. Armstrong, 263 S.C. 594, 211 S.E.2d 889 (1975); Texas, TEx. Code Cram. Proc. ANN. art. 1.15 (Vernon 1973); Vermont, VT. R. Crms. P. 11(f); Washington, WASH. SuPER. CT. Crm. R. 4.2(d); Wisconsin, Salters v. State, 52 Wis. 2d 708, 191 N.W.2d 19 (1971), Wis. Stat. Ans. $971.08(1)(\mathrm{b})$ (1971). 
guilty to misdemeanor charges ${ }^{7}$ are rarely accorded similar protection.

This Article will discuss the development of and rationale for the accuracy inquiry. In addition to demonstrating that application of the accuracy requirement to all guilty pleas will enhance the quality of American criminal justice without producing undue costs for the lower courts, the following discussion will reveal that no difference between felony and misdemeanor charges can justify the decision to apply the accuracy requirement solely to felony cases. Rather, this Article proposes that an accuracy inquiry be extended to all felony and misdemeanor guilty pleas in state as well as federal courts. A standard for the accuracy inquiry will be proposed that is consistent with the procedural safeguards required within an adversarial system of justice ${ }^{8}$ that nonetheless recognizes the seemingly intractable problems facing the courts.

\section{Procedural Protections and the Guilty Plea}

The protections afforded a defendant during the plea process fall into the general categories of intelligence, voluntariness, and accuracy. They are implemented by inquiries made at the time the plea is offered. ${ }^{9}$ The intelligence inquiry is to ensure that the defendant understands the nature of the charge and the consequences of his plea. ${ }^{10}$ The voluntariness inquiry is to ensure that

7 Although states vary as to the manner in which offenses are classified as misdemeanors or felonies, see Kamisar \& Choper, The Right to Counsel in Minnesota: Some Field Findings and Legal-Policy Observations, 48 MivN. L. Rev. 1, 64-67 (1963), the most widely adopted standard is that a misdemeanor is an offense punishable by not more than one year's imprisonment. See Modex Penat Code $\$ 1.04$ (Proposed Final Draft No. 1, 1961). Therefore, in this Article the term "misdemeanor" will be used to refer to offenses punishable by a fine or imprisonment not exceeding a term of one year.

8 Implicit in this proposal for a procedural solution to the accuracy problem surrounding guilty pleas is an assumption that a more formalized procedure is the most effective. In this respect, the argument favors a procedure consistent with the due process model of criminal procedure as described by the late Professor Herbert L. Packer. See H. Packer, The Lmits of the Crminnal Sanction 149-73 (1968). For an argument that, at least in the lower courts, less, rather than more formalized procedure may be the answer, see, Griffiths, Ideology in Criminal Procedure or a Third "Model" of the Criminal Process, 79 YALE L.J. 359 (1970).

9 The accuracy inquiry may be made after the plea providing it is completed prior to judgment or sentence. See cases cited in note 228 infra \& accompanying text.

10 The concept of intelligence has also been expressed as "understanding," Kercheval v. United States, 274 U.S. 220, 233 (1927), or "knowing." Fontaine v. United States, 411 U.S. 213 (1973). A guilty plea is valid only if "made voluntarily after proper advice and with full understanding of the consequences." Kercheval, supra, at 223. For a list of the concerns generally regarded as part of the "understanding" or "intelligence" aspect of the plea, see ABA Prea StandarDs, supra note 2 , at $\$ 1.4$. 
no defendant offers a plea because he is the victim of impermissible pressures. ${ }^{11}$ Together the intelligence and voluntariness inquiries should demonstrate that a defendant understands 1) that impermissible pressures may not be used to secure his plea; 2) the nature of the charge against him; ${ }^{12}$ 3) that a plea waives certain constitutional rights, ${ }^{13}$ and 4) that certain consequences will follow a plea conviction. ${ }^{14}$ Regardless of the vigor with which the intelligence and voluntariness inquiries are pursued, that effort is largely wasted if a defendant is allowed to plead unknowingly to a charge within which his conduct does not fall. The purpose of the accuracy inquiry is precisely to ensure that no defendant offers a plea "without realizing that his conduct does not actually fall within the charge." 15

The voluntariness/intelligence ${ }^{16}$ and accuracy protections differ in their derivation, historical periods of development, and in the

11 "A guilty plea, if induced by promises or threats which deprive it of the character of a voluntary act, is void." Machibroda v. United States, 368 U.S. 487, 493 (1962). Judicial inquiries as to voluntariness are concerned about the use of violence, threatened violence, inducements, deception, and trickery. The voluntariness inquiry considers the following factors: (I) the defendant's understanding of permissible inducements to the plea; (2) the defendant's understanding of the nature of the charge; (3) the defendant's understanding of the consequences of his plea (i.e. the maximum sentence, mandatory minimum sentence, eligibility of parole, possible collateral consequences); (4) the defendant's knowledge as to the constitutional rights he waives when he chooses to plead. A defendant should be informed of the rights waived by a plea of guilty. Voluntariness is not always easy to define, and, as will be seen, is frequently combined with the "understanding" requirement. "Voluntariness" has been characterized as "exceedingly ambiguous," Courts, supra note 2, at 108, 116, and as having "chameleon-like properties," J. BoND, PLEA Bargating and Guilty Pleas 75 (1975).

12 "[R]eal notice of the true nature of the charge ... [is] the first and most universally recognized requirement of due process .... Smith v. O'Grady, 312 U.S. 329, 334 (1941); see Henderson v. Morgan, 426 U.S. 637, 645 (1976); FED. R. CRnar. P. I1(c)(1); ABA PLEA Standards, supra note 2, \$1.4(a) \& commentary.

13 In Boykin v. Alabama, 395 U.S. 238, 243 (1969), the Court indicated that a plea of guilty waives (1) the privilege against compulsory self-incrimination, (2) the right to trial by jury, and (3) the right to confront one's accusers. There is considerable disagreement among the states as to whether those three rights, commonly referred to as the Boykin rights, must be specifically waived on the record. See J. Bond, supra note 11 , at $\$ 3.08$; F. InBaU, CASES and Conments on Crantonar Procedure 813-14 (1974).

${ }^{14}$ Although a defendant must understand the "consequences" of his plea, this has been limited to the "direct consequences." Brady v. United States, 397 U.S. $742,755(1970)$. The dispositional alternatives that are of concern to the courts are minimum and maximum sentences, consecutive sentencing possibilities, applicable habitual offender statutes, and ineligibility for parole. See FED. R. CRIM. P. 11(c) (1); ABA PLIAA STANDARDS, supra note 2, at \$1.4(c) \& commentary; AII MODEL Code of Pre-Arratgnment Procendre \$ 350.4, commentary at 618-20 (Proposed Official Draft 1975); J. BoND, supra note 11, at $\$ 3.38-.42$.

15 MicCarthy v. United States, 394 U.S. 459, 467 (1969) (quoting Advisory Committee Notes to FED. R. Crms. P. 11).

16 It is sometimes difficult to discem where the concept of "voluntariness" ends and that of "intelligence" begins. The voluntariness and intelligence requirements 
amount of legal commentary devoted to each. Voluntariness has emerged from a long line of Supreme Court decisions as a constitutionally compelled due process requirement. ${ }^{17}$ Its contours and ramifications have attracted extensive attention within the legal literature. ${ }^{18}$ The accuracy requirement, on the contrary, stems from policy ${ }^{10}$ rather than constitutional considerations. ${ }^{20}$ It has come into prominence only within the last decade, and rarely has it been the subject of critical analysis. ${ }^{21}$ The most significant distinction between the voluntariness and accuracy protections, however, is in the breadth of their application. The utilization of the two protections has come to depend upon the category of crime charged (felony or misdemeanor), the jurisdiction within which the crime was allegedly committed, and the sovereign levying the charge (federal, state or municipal).

There is also a major transactional difference between the voluntariness and the accuracy inquiries with respect to the direction of information flow. In the voluntariness inquiry, ${ }^{22}$ the flow of information is from the judge to the defendant. In the accuracy inquiry, in contrast, flow is from the defendant to the judge. ${ }^{23} \mathrm{Be}$ -

are sufficiently similar that, for purposes of this Article, the two requirements can be grouped together to facilitate comparison with the accuracy requirement. $C f$. J. BoND, supra note 11 , at $\$ 3.02$ (grouping together voluntariness and intelligence requirements for guilty plea acceptance). Hereinafter, only the word "voluntary" or "voluntariness" will appear although "intelligence" is also intended unless specifically excluded.

17 See, e.g., Tollett v. Henderson, 411 U.S. 258 (1973); North Carolina v. Alford, 400 U.S. 25 (1970); McMann v. Richardson, 397 U.S. 759 (1970); Parker v. North Carolina, 397 U.S. 790 (1970); McCarthy v. United States, 394 U.S. 459 (1969); Uveges v. Pennsylvania, 335 U.S. 437 (1948); Von Moltke v. Gillies, 332 U.S. 708 (1948); Foster v. Illinois, 332 U.S. 134 (1947); Carter v. Illinois, 329 U.S. 173 (1946); Williams v. Kaiser, 323 U.S. 471 (1945); Waley v. Johnston, 316 U.S. 101 (1942); Walker v. Johnston, 312 U.S. 275 (1941); Kercheval v. United States, 274 U.S. 220 (1927).

18 See, e.g., sources cited in M. Marcus \& R. Wheaton, Plea Bargaintng: A SETECTED BibliograpHY (1976).

19 See McCarthy v. United States, 394 U.S. 459, 465 (1969).

20 For a discussion of the argument that the factual basis requirement is required by the due process clause, see note 156 infra.

21 Legal literature on the plea process at most alludes briefly to the accuracy requirement and is mainly devoted to voluntariness considerations. Exceptions include Note, Standards for Accepting Guilty Pleas to Misdemeanor Charges, $8 \mathrm{U}$. MrCr. J.L. ReF. 568 (1975) and Note, The Trial Judge's Satisfaction as to the Factual Basis of Guilty Pleas, 1966 WASH. U.L.Q. 306, in addition to various case notes on relevant Supreme Court opinions.

22 See note 11 supra.

23 The judge must ascertain whether the defendant's acts and intent are those required for the crime to which he pleaded, or for a more serious crime. ABA PLEA STANDARDS, supra note 2 , at 33 . The judge makes this judicial verification of guilt after comparing the expressed factual basis for this defendant's activity to the required factual basis for the crime. 
cause there is less need for individualized treatment when a judge is providing information to a defendant, some states have provided alternatives to the method of personal interrogation for determining the voluntariness of a misdemeanor plea ${ }^{24}$ by using group arraignments ${ }^{25}$ or by using printed forms, ${ }^{28}$ even though both of these methods have drawbacks. ${ }^{27}$

Although voluntariness is constitutionally required in every jurisdiction for every category of crime, the accuracy requirement has a narrower applicability. Rule 11 of the Federal Rules of Criminal Procedure ${ }^{28}$ mandates an accuracy requirement for all guilty pleas in federal courts. Although many states have a similar requirement ${ }^{20}$ when the charged offense is a felony, it has scant application in the states as to misdemeanors. ${ }^{30}$ This artificial distinction between felonies and misdemeanors inevitably perpetuates

24 States apparently read Boykin to require personal interrogation; as a result, alternative methods have not been used in felony pleas. States that employ alternatives for misdemeanors attempt to distinguish Boykin by limiting it to felony pleas.

25 See, e.g., In re Johnson, 62 Cal. 2d 325, 398 P.2d 420, 42 Cal. Rptr. 228 (1965); Mills v. Municipal Court, 10 Cal. 3d 288, 515 P.2d 273, 110 Cal. Rptr. 329 (1973).

26 See, e.g., In re Birch, 10 Cal. 3d 314, 515 P.2d 12, 110 Cal. Rptr. 212 (1973); Mills v. Municipal Court, 10 Cal. 3d 288, 515 P.2d 273, 110 Cal. Rptr. 329 (1973). A court may use forms to inform the defendant of the proper or improper pressures that might be applied to him and the probable consequences of his plea. In addition, the forms can become part of the record.

27 The use of group arraignments does not fulfill the objectives of the plea. Obviously the judge is acting personally, but the address to the group renders the effect of personal interrogation a nullity. Although the use of forms is ostensibly less time consuming, it is clearly less satisfactory than direct interrogation. More total time will be expended filling out forms and reading them than if the defendant were interrogated by the judge on the record. The use of forms also would eliminate the opportunity of the judge to infer and pursue indications of involuntariness that would be demonstrated by the defendant's hesitation in answering voluntarinesss questions.

28 Note 5 supra.

29 Note 6 supra.

30 The majority of jurisdictions have not applied the factual basis requirement to misdemeanors. Six states, however, have enacted statutes or court rules which, either expressly or through judicial interpretation, require a factual basis to be determined in guilty pleas to misdemeanor charges. Arrz. R. CrnM. P. 17.1(b) \& 17.3 (1975) (excluding minor traffic offenses); FLA. R. CrIM. P. 3.010, 3.170(j); KAN. STAT. ANN. $\$ 22-3210(4)$ (1974) (by implication, as other procedures in the plea rule are limited to felony cases); Mice. Dist. Cr. R. 785.4; N.J. Mur. Cr. R. 7:4-2(b); OnIo Rev. Code ANN. \$2937.07 (Page 1975); accord, City of Cleveland v. Whipkey, 29 Ohio App. 2d 79, 278 N.E.2d 374 (1972).

In Illinois, a factual basis is strongly recommended if the offense charged is punishable by imprisonment. People v. Bailey, 12 Ill. App. 3d 779, 301 N.E.2d 481 (1973) (dictum); People v. Trinka, 10 Ill. App. 3d 183, 293 N.E.2d 179 (1973). Although Pennsylvania does not specifically require a hearing to establish the factual basis of a plea, such is the preferred practice. PA. R. CRm. P. 319 \& comment.

Only Texas has specifically held that a factual basis need not be established for a misdemeanor plea. See Buchanan v. State, 480 S.W.2d 207, 211 ('Tex. Crim. App.), appeal dismissed, 409 U.S. 814 (1972). 
a tendency in the lower court system to dispense what has appropriately been called "assembly-line justice." 31 The procedural protections that will be provided to defendants accused of identical criminal acts will thus depend upon the jurisdiction within which they are prosecuted and the authorities-federal, state, or localresponsible for the prosecution. The irony of this procedural disparity is that, although only a voluntariness inquiry is constitutionally required, the protection it affords is circumvented without an equally effective accuracy inquiry.

Because accuracy inquiries have in fact improved the quality and credibility of the plea process for felonies, ${ }^{32}$ it is reasonable to anticipate that accuracy inquiries would produce a corresponding improvement in the quality of misdemeanor pleas. But defendants charged with misdemeanors generally, have not been afforded the same accuracy protection as those charged with felonies. This disparity is typical of that imbalance within American criminal justice which tolerates an inferior, highly criticized strata of lower courts ${ }^{33}$ which are rarely the beneficiaries of genuine reform. ${ }^{34}$

31 Argersinger v. Hamlin, 407 U.S. 25, 36 (1972).

32 The factual basis requirement has been referred to as perhaps the most important aspect of the plea proceedings. 8 Moore's Federar Practice $\{11.01[1]$, at 11-5 (2d ed. Supp. 1976). But see State v. LeGear, 187. Neb. 763, 766, 193 N.W.2d 763 (1972) (Newton, J., dissenting) (when defendant had information served upon him, the statute read to him, and accompanied by his retained counsel, he entered a plea of guilty, the dissent stated "[f]or the court to be required to inquire further into the facts pertaining to the offense would be to require a superfluous act and verges on the ridiculous").

33 See, e.g., S. Bing \& S. Rosenfexd, The Quatuty of Justice IN THE Lower Cemmenal Courts of Metropoltran Boston (1970); L. Downne, Justice Denied (1971); H. James, Crusis in the Courts (1968); R. Moler, Our Crnimal Courts (1930); D. Oaks \& W. Lemman, A Crmminal Justice System and the Indigent (1988); The Presment's Commisston on Law Enforcement and adoministration of Justice, TAsk Force Repont: The Counts (1967); Barrett, Criminal Justice: The Problem of Mass Production, in THE Courts, TPE PUBLIC, AND THE Iaw Explosion 85 (H. Jones ed. 1965); RovGH JUSTICE (J. Robertson ed. 1974); MAsS Production Justice and TRE Constrututronal Ineal (C. Whitebread ed. 1970); Katz, Municipal Courts-Another Urban Ill, 20 CASE W. Res. I. Rev. 87 (1968); Platt, An Odd Couple: The Criminal Sanction and the Municipal Ordinance, 7 WuLANETTE L.J. 43 (1971); Note, Inferior Couts in Alabama, 24 ALA. L. Rev. 509 (1972); Note, Metropolitan Criminal Courts of First Instance, 70 HAnv. L. Rev. $320(1956)$.

34 Although some improvements in the lower courts have occurred as a result of Supreme Court decisions, cases cited note 109 infra, defendants in lower courts typically receive diluted justice. Compare Gideon v. Wainwright, 372 U.S. 335 (1963) (counsel must be appointed for all indigent defendants charged with felonies) with Argersinger v. Hamlin, 407 U.S. 25 (1972) (counsel must be appointed only for those indigent defendants upon whom imprisonment is imposed). 


\section{Benefits of an Accuracy Requirement}

An accuracy requirement for a valid plea is fulfilled by establishing a factual basis ${ }^{35}$ for the plea to the satisfaction of the judge accepting the plea. ${ }^{86}$ The factual basis determination may (1) assist a judge in the voluntariness determination, ${ }^{37}$ (2) make appellate review of a plea less complex, ${ }^{38}$ (3) facilitate the rehabilitation of a defendant, ${ }^{38}$ and (4) provide protection for an innocent defendant. ${ }^{40}$

The most frequently advanced and widely accepted justification for a factual basis requirement is the protection rationale. As initially explained by the Advisory Committee to the federal rules, its purpose is "[to] protect a defendant who is in the position of pleading voluntarily with an understanding of the nature of the charge but without realizing that his conduct does not actually fall within the charge." 41 The protection rationale has been adopted by many courts. ${ }^{42}$ It is based on the assumptions that some innocent defendants will offer guilty pleas, and that these defendants can be protected if a factual basis is required before their pleas are accepted. An examination of these assumptions confirms the validity of the protection rationale.

A central concern of any system of criminal justice is to make certain that innocent defendants are not convicted. ${ }^{43}$ Because the American criminal justice system provides adversarial trials in which anyone accused of criminal activity may contest his guilt, a pre-

35 An "accuracy inquiry" is the process of determining what acts and intent can be attributed to the defendant. If the acts and intent uncovered through the accuracy inquiry correspond to the elements of the crime to which the plea is offered, a "factual basis" for the plea is said to exist. In practice, the terms "factual basis" and "accuracy inquiry" are often used interchangeably.

${ }^{36}$ A court must satisfy itself that a factual basis exists. FED. R. CRnM. P. 11(f). The test is clearly subjective. I C. Wrught, Federal Practice and Procedoure $\$ 174$, at 376 (1969).

37 McCarthy v. United States, 394 U.S. 459, 465-67 (1969).

38 Id. 467.

39 A guilty plea following plea negotiations, by shortening the time between charge and disposition, "enhances whatever may be the rehabilitative prospects of the guilty when they are ultimately imprisoned." Santobello v. New York, 404 U.S. 257, 261 (1971). But see New York State Spectal Conmission on AtrTCa, Atrica 30-31 (1972).

40 McCarthy v. United States, 394 U.S. 459, 467 (1969).

41 Advisory Committee Notes to the 1966 amendment of FED. R. CFn. P. 11.

42 E.g., McCarthy v. United States, 394 U.S. 459, 467 (1969); Brown v. State, 250 A.2d 503, 505 (Del. 1969); McCall v. State, 9 Md. App. 191, 199, 263 A.2d 19,25 (1970).

43 See J. Rawns, A Theory of Jostice (1971). "The desired outcome is that the defendant should be declared guilty if and only if he has committed the offense with which he is charged." Id. 85. D. NEwaran, supra note 2, at 232; Hart, The Aims of the Criminal Law, 23 L. \& ConteMP. Prob. 401 (1958). 
sumption arises that innocent defendants will in fact contest charges lodged against them. Innocent defendants may nonetheless offer pleas rather than contest their guilt at trial for several reasons. Innocent pleaders can be divided conceptually into two different subcategories. Those in the first group, because of the complexity of the criminal law, erroneously conclude that they have committed the crime charged although in fact they have not. ${ }^{44}$ The second group is comprised of individuals who, because of prior experiences or pressures applied to them as they are processed through the criminal justice system, conclude that it is in their best interest to plead guilty although they know they did not commit the crime with which they are charged.

A defendant who pleads guilty because of an erroneous conclusion regarding his guilt ${ }^{45}$ may do so because of one or more reasons: (1) confusion as to his prior actions, ${ }^{46}$ (2) failure to understand that criminal liability requires both an act (or omission) and intent, $^{47}$ (3) inability to understand that both the act and intent must be considered criminal, ${ }^{48}$ (4) failure to understand that there is no crime unless the act and intent concur, ${ }^{49}$ (5) failure to realize in a particular circumstance that transferred intent may not be applicable, ${ }^{50}$ and (6) failure to recognize other appropriate defenses. ${ }^{51}$

An innocent defendant who is aware that he did not commit the criminal act might nevertheless decide to plead guilty because of: (1) the potentially overwhelming nature of the evidence against

44 See aBa Project on Standards for Caminad Justice, Standards Retating to the Prosecution Function and the Defense Function 226-27 (App. Draft 1971) [hereinafter cited as ABA DeFEnse StaNDARDs].

45 "It is not difficult to imagine an accused standing before the bar of justice accused of a crime he thinks he committed but really did not." Estes v. State, 294 So. 2d 122, 123 (Fla. Dist. Ct. App. 1974), affd, 316 So. $2 d 276$ (Fla. 1975).

46 The defendant may not remember the details of his allegedly criminal activities. It is also possible that the defendant in fact previously committed the type of offense charged, but not at the time and place charged. Because of his confusion regarding his prior conduct, however, he may erroneously believe that he committed the act as charged.

47 "[A] man is not punished merely because he has a criminal mind." Smith, Two Problems in Criminal Attempts, 70 Harv. L. Rev. 422, 447 (1957).

48 See ABA Defense Standards, supta note 44.

49 See United States v. Rogers, 289 F.2d 433 (4th Cir. 1961) (subsequent conversion of innocently accepted overpayment cannot sustain a conviction for larceny).

50 Transferred intent does not apply if there is a difference between the type of harm intended and the type of harm resulting. See MODEx. PENaL CoDE $\$ 2.03(2)$ (Official Draft 1962). See generally W. LaFave \& A. Scotr, HandBook on Gamminal Law 243-44 (1972).

51 Possible defenses include entrapment, duress, self-defense, defense of another, and defense of property. See generally W. LAFAvE \& A. ScoTr, supra note 50, at 268-413. 
him; ${ }^{62}$ (2) the disparity in punishment between conviction by plea and conviction at trial; ${ }^{63}$ (3) a desire to protect family or friends from prosecution; ${ }^{54}$ (4) the conditions of pretrial incarceration; ${ }^{55}$ (5) a concern that fuller inquiry at trial may result in disclosure of additional facts which could increase the sentence in the present case or result in additional prosecutions; ${ }^{\sigma \theta}(6)$ a desire to expedite the proceedings because of feelings of hopelessness, powerlessness, or despair when faced with the power of the state; ${ }^{57}$ (7) pressure from family, friends, or attorneys; ${ }^{58}$ and (8) "ignorance, deception, delusion, feelings of moral guilt, or self-destructive inclinations." 59

Given the fact that innocent defendants do plead guilty, ${ }^{60}$ an analysis of the effects of a trial judge's determination that there is an insufficient factual basis ${ }^{61}$ for him to accept a guilty plea indicates whether defendants receive sufficient protection in this manner.

52 See, e.g., State v. Reali, 26 N.J. 222, 139 A.2d 300 (1958) (plea entered because defendant was told by his attorney that his pretrial escape was tantamount to signing a confession). For documented cases of innocent defendants who were convicted at trial, see E. Borchard, Convicting the InNocenNT (1932); J. Frank \& B. Frans, Not GumTY (1957).

53 The problem of disparity is a major concern of the sentencing process. Courts, supra note 2, at 23-24. For several views on the desirability of this disparity, compare Pilot Institute on Sentencing: Proceedings, 26 F.R.D. 231, 285-87 (1959) ("willingness [of a defendant] to plead guilty ought not to have any independent significance in sentencing." Id. 285), with ABA PLEA STANDards, supra note 2 , at $\$ 1.8$ ("It is proper for the court to grant charge and sentence concessions to defendants who enter a plea of guilty . . . ." Id.).

54 See, e.g., Cortez v. United States, 337 F.2d 699 (9th Cir. 1964) (defendant's guilty plea entered in exchange for promise that his pregnant wife would be allowed to plead guilty to a lesser charge); Kent v. United States, 272 F.2d 795 (1st Cir. 1959) (plea induced by promise not to prosecute defendant's fiancee).

55 See Newbold v. State, 492 S.W.2d 809, 814 (Mo. 1973) (defendant pleaded guilty in order to be transferred out of city jail); People v. Johnson, 33 App. Div. 2d 573,305 N.Y.S.2d 274 (1969) (plea entered to obtain hospital treatment for narcotic addiction); White, A Proposal for Reform of the Plea Bargaining Process, 119 U. PA. L. REv. 439, 44 (1971).

56 A. Amsterdaim, B. Segal \& M. Muller, Trual Manual for the Defense of Cruminat Cases $\$ 202$ at I-189 to 190 (3d ed. 1975).

ธ7 See, e.g., Morgan v. State, 287 A.2d 592, 603 (Me. 1972).

58 See, e.g., People v. Heirens, 4 Ill. 2d 131, 122 N.E.2d 231 (1954), cert. denied, 349 U.S. 947 (1955) (pressure from defense attorneys and parents).

50 State v. Durham, 108 Ariz. 327, 329, 498 P.2d 149, 151 (1972).

60 Finkelstein, A Statistical Analysis of Guilty Plea Practices in the Federal Courts, 89 Harv. L. REv. 293, 309-11 (1975). The exact number of innocent people who plead guilty is uncertain, however. Courrs, supra note 2, at 108 app. 113.

01 It should be noted that of the situations that might induce innocent defendants to plead guilty, text accompanying notes 52-59 supra, only the overwhelming nature of the evidence would be likely to produce a sufficient factual basis for a judge to accept a plea of guilty. 
A guilty plea cannot be accepted in federal court without demonstration of a factual basis for the plea. ${ }^{62}$ Therefore, an insufficient factual basis eliminates the option of pleading guilty and requires a defendant to stand trial. This procedure will be referred to as the "trial-factual-basis procedure." Some states have adopted the "trial-factual-basis procedure." Others, however, simply require that a defendant be notified of the factual basis defect in his plea, thereby presenting him with the option of standing trial or having his plea accepted despite the defect. ${ }^{63}$. This latter procedure will be referred to as the "notice-factual-basis procedure." Assuming all parties present the truth, the inability to establish a suffcient factual basis might indicate that a defendant's guilt could not be proven beyond a reasonable doubt. A finding of insufficient factual basis is, however, hardly equivalent to a verdict of not guilty. The defendant may be convicted at trial even though a sufficient factual basis could not be established for the plea. This may be so either because the information presented for factual basis purposes was less than the admissible evidence available for trial, ${ }^{64}$ or because conflicts among sources of information used to establish a factual basis, which would preclude the judge from accepting the plea, ${ }^{65}$ might be resolved against the defendant at trial. The protection afforded the defendant by the factual basis requirement, therefore, does not mean that every innocent defendant will avoid conviction. Rather, it means only that those defendants who, prior to the factual basis inquiry, were not aware that their conduct did not fall within the charge are either forced to trial, or are put on notice that they possibly could be acquitted at trial, and are required to choose between a plea or trial. It does not guarantee that those who go to trial will be acquitted; nor does it guarantee that they will not be subjected to a harsher penalty for unsuccessfully attempting to prove their innocence. ${ }^{66}$

A discussion of innocence, of course, can be approached from either a factual or legal perspective. For the purposes of this

62 Fed. R. CRm. P. $11(f)$.

63 "If after proper notice defendant nevertheless wishes to convict himself, the court can accept the plea." Comment, Judicial Supervision Over California Plea Bargaining: Regulating the Trade, 59 CAL. L. Rev. 962, 981 (1971). See People v. Serrano, 15 N.Y.2d 304, 309-10, 206 N.E.2d 330, 332-33, 258 N.Y.S.2d 386, $389-90$ (1965).

64 Not all witnesses who could be called to testify at trial are likely to be present at the plea proceeding.

65 See note 274 infra \& accompanying text.

66 See note 53 supra. 
Article, factual innocence means that an accused's conduct cannot be defined as criminal. In other words, a defendant is factually innocent if he did not commit a voluntary act (or omission) with the requisite intent; conversely, he is factually guilty if he did. Legal innocence, on the other hand, is defined as either a dismissal of the charges for a reason of law ${ }^{67}$ or a verdict of not guilty returned by the trier of fact. An accused is legally innocent if the trier of fact concludes that the admissible evidence does not prove his guilt beyond a reasonable doubt. If the evidence does so prove, the defendant is legally guilty. In this sense, the legal definition of guilt or innocence is defined by the judicial process. ${ }^{68}$

An interrelationship between fact and law exists in all criminal trials. Frequently fact and law correspond perfectly; factually innocent defendants are found legally innocent. The legal outcome, however, does not always coincide with the factual event. Through policy decisions to employ such concepts as the presumption of innocence, reasonable doubt, burden of proof, and the exclusionary rules of evidence, the criminal justice system has been designed to ensure that as many factually innocent defendants as possible will be protected from conviction, even though those policy decisions result in some factually guilty defendants being found legally innocent. ${ }^{69}$ Independent of such policy decisions, discrepancies between fact and legal outcome may stem from mistakes in decisionmaking processes. ${ }^{70}$ As a result, some factually innocent defendants will be found legally guilty; some factually guilty defendants will be found legally innocent. Although finding a factually guilty defendant legally innocent is a type of mistake tolerable in an adversary system that seeks to preserve the dignity of the individual as well as to pursue truth, finding a factually innocent defendant legally guilty is unacceptable. The criminal justice system must implement procedural protections in order to prevent such malfunctions.

67 For example, double jeopardy considerations may require the dismissal of charges against defendants who are factually guilty.

68 [The defendant] is [legally] guilty if and only if [the] factual determinations are made in procedurally regular fashion and by authorities acting within competences duly allocated to them. Furthermore, he is not to be held [legally] guilty, even though the factual determination is or might be adverse to him, if various rules designed to protect him and to safeguard the integrity of the process are not given effect: ... jurisdiction .... venue ... statute of limitations ... double jeopardy ... criminal responsibility. ...

H. PACKER, supra note 8, at 166.

60 Id. 167; Christie \& Pye, Presumptions and Assumptions in the Criminal Law, 1970 DukE L.J. 919, 927 (1970).

70 See E. Borchard, Convicting the Innocennt (1932); J. Frank \& B. Frank, Not GUILTY (1957). 
Because legal guilt is usually determined by the waiver of trial and a plea of guilty or nolo contendere, ${ }_{9}^{71}$ a defendant's willingness to offer a plea does not insure that legal guilt is based on factual guilt. A factual basis requirement, however, can protect those pleaders who are innocent in either fact or law. ${ }^{72}$

The subgroup of defendants who erroneously conclude that they were factually guilty but who would be acquitted at trial would certainly benefit from a factual basis requirement. They will be acquitted at a trial required under a trial-factual-basis procedure; under a notice-factual-basis procedure they will be given notice of their possible legal innocence and the opportunity to stand trial and be acquitted. Those people who are both factually and legally innocent but lack the strength to seek their legal innocence must stand trial under a trial-factual-basis procedure; under a notice-factual-basis procedure they will be given the opportunity to make: a more realistic evaluation of their situation. Those people who are both factually and legally innocent but see a greater benefit in a plea than a trial would still be able to exercise that option under a notice-factual-basis procedure.

The probability of establishing the legal innocence of the factually innocent defendant who decides to plead guilty under the above-mentioned circumstances is sufficiently great, and the damage to the legal system by allowing him to be convicted albeit by his own plea is so severe, that all federal and many state courts require the accuracy inquiry for felony pleas. The application of such a procedure should be extended to all criminal pleas. Indeed, the accuracy inquiry would accomplish its purpose even more frequently with misdemeanor pleas.

\section{IMPORTANCE OF THE ACCURACY INQUIRY FOR MISDEMEANORS}

The accuracy inquiry is even more necessary for people accused of misdemeanors rather than felonies.' A misdemeanor defendant is less likely to receive any significant benefit by offering a guilty

71 See note 2 supra \& accompanying text.

72 It has generally been assumed that there is no way of determining how many factually innocent defendants who plead guilty would be acquitted if they went to trial. One study, however, has concluded that up to one third of all defendants pleading guilty would escape conviction by going to trial. See Finkelstein, supra note 60 at 309-10. A trial-factual-basis procedure, of course, would be detrimental to a defendant convicted at trial despite his factual innocence, to the extent that he suffers sentence disparity. See note 53 supra. In this sense, the trial-factual-basis procedure either purposefully neglects or fails to recognize the plight of those defendants who are factually innocent but would be legally guilty. 
plea. He appears in a type of court that historically has rendered less protection to those charged with a misdemeanor than to those accused of a felony.

A factually innocent defendant charged with a felony may rationally choose to plead guilty in certain circumstances. The overwhelming nature of the evidence against him may lead him to conclude either that he would be convicted at trial, ${ }^{73}$ or that the probable sentence disparity between plea and trial is so great that it is in his best interests to offer a plea. Although a felony defendant may see distinct benefits in a negotiated plea, a defendant initially charged with a misdemeanor is already charged with the least severe category of crime in the jurisdiction. As a result, the usual benefits associated with a negotiated plea will not be available. Although the Supreme Court has sustained guilty pleas offered by felons who simultaneously proclaimed their innocence when the plea was offered at the suggestion of competent counsel who hoped to limit the possible penalty, ${ }^{74}$ if no conclusive benefit could be achieved by offering a plea, a court should scrutinize the factual basis exactingly. This would be the case with nearly every misdemeanor charge. When the original charge is a misdemeanor, virtually no formal plea negotiation occurs; ${ }^{75}$ the small range of sentence lengths offers little opportunity for tacit bargaining. Therefore, when a notice-factual-basis procedure is employed, a defendant who learns that there is no factual basis for his crime will more likely opt for a trial in a misdemeanor case.

In addition to the minimal benefit of a plea in a misdemeanor case, other characteristics of misdemeanor courts suggest the importance of an accuracy inquiry in that context. Even though defendants charged with misdemeanors enjoy most of the constitutional rights guaranteed to defendants charged with felonies, ${ }^{76}$

73 The defendant in North Carolina v. Alford, 400 U.S. 25 (1970), for example, had a long prior criminal record which included convictions for murder, armed robbery (nine times), transporting stolen goods, forgery, and carrying a concealed weapon. Although a jury would have been instructed to consider the prior convictions only on the issue of credibility and not as substantive evidence, they might have been hard pressed to do so. Such an instruction would amount to "[a] recommendation to the jury of a mental gymnastic which is beyond, not only their powers, but anybody's else." Nash v. United States, 54 F.2d 1006, 1007 (2d Cir. 1932).

74 North Carolina v. Alford, 400 U.S. 25 (1970).

75 The President's Commisston on Law Enforcentent and Adninistration of Justice, The Charlenge of Crane in a Free Society 134 (1967) thereinafter cited as Chatrenge of Crane].

76 Argersinger v. Hamlin, 407 U.S. 25 (1972) (right to counsel when imprisonment is imposed); Mayer v. City of Chicago, 404 U.S. 189 (1971) (right to transcript for purposes of appeal); District of Columbia v. Clawans, 300 U.S. 617 (1937) (right to confront one's accusers); Counselman v. Hitchcock, 142 U.S. 547 (1892) 
differing procedures have been justified on the basis of the consequences, complexity, and volume of misdemeanor cases. It has been said that the consequence is mild, 77 the complexity slight, and the volume overburdening.

Misdemeanors are often referred to as "petty" offenses, but "petty" is a misleading term. ${ }^{78}$ A closer examination discloses that the consequences of being convicted of a "petty" offense are not at all trivial. ${ }^{79}$. From the point of view of the individual defendant, a misdemeanor conviction has significant, long-lasting deleterious effects. The length, conditions, and consequences of imprisonment, as well as the lingering status of "misdemeanant," are far from trivial. "[T] he prospect of imprisonment for however short a time will seldom be viewed by the accused as a trivial or petty matter and may well result in quite serious repercussions affecting his career and reputation." so "To look only at the length of incarceration provided by the misdemeanor statute as a measure of the seriousness of the consequences of conviction may be a deceptive measure of severity because a misdemeanant's incarceration may exceed the apparent, statutory limit by a considerable amount. Conviction may lead to consecutive sentences if the defendant was charged with multiple counts. ${ }^{81}$ Moreover, conviction may be an automatic violation of felony probation or parole, subjecting the defendant to a long prison term..$^{2}$

Regardless of its length, the severity of a misdemeanor incarceration may be attributable to the place of incarceration. Although the conditions of any prison may be unpleasant, the mis-

(privilege against self-incrimination). The major constitutional difference is in the right to trial by jury. See Baldwin v. New York, 399 U.S. 66 (1970). (1973).

77 E.g., People v. Tomlinson, 50 Mich. App. 655, 659, 213 N.W.2d 803, 805

78 "Generally speaking, petty offenses are a sub-group of misdemeanors; that is, a felony is necessarily a major crime, but a misdemeanor may be either a major crime or a petty offense depending on the possible punishment." W. LAFAVE \& A. Scotr, supra note 51 , at 33 .

79 Although the offense might be termed "petty" with respect to the "type of offenses and to the penalties imposed, it nevertheless has a tremendous impact on citizens having their first and perhaps only contact with the criminal justice system." Oliphant, Reflections on the Lower Coutt System: The Development of a Unique Clinical Misdemeanor and a Public Defender Program, 57 MrNN. L. Rev. 545, 546 (1973).

80 Baldwin v. New York, 399 U.S. 66, 73 (1970).

81 See, e.g., Hendrix v. City of Seattle, 76 Wash. $2 d$ 142, 456 P.2d 696, cert. denied, 397 U.S. 948 (1969), overruled on other grounds, 85 Wash. 704, 538 P.2d 499 (1975).

82 See Sweeton v. Sneddon, 324 F. Supp. 1094 (N.D. Utah 1971) (defendant faced a penalty of up to six months and/or a $\$ 300$ fine on misdemeanor conviction, and was subject to imprisonment for as long as 17 years and five months if his felony parole was revoked). 
demeanant's place of incarceration may be far worse than the felon's. In most states misdemeanants are incarcerated in local jails. Although state and federal prisons have been severely criticized, ${ }^{83}$ the conditions of many local jails are far worse than those of even the most inadequate state and federal institutions. Incarceration may subject the misdemeanant to "deplorable living conditions" 84 in jails that are often little more than the ill-equipped remnants of the last century, manned by untrained people with few professional skills. ${ }^{85}$ Structural and personnel deficiences are not the only problems. Health care is often minimal or nonexistent; ${ }^{86}$ a prisoner may be subject to threats of violence, sexual assaults, ${ }^{87}$ and suicidal pressures. ${ }^{88}$

In addition to curtailing liberty, incarceration can mean the loss of employment, creating financial hardships for a defendant and his family. ${ }^{\text {s9 }}$ The community may eventually suffer from a misdemeanant's association with felons during pre-trial incarceration. ${ }^{90}$

83 See, e.g., Finney v. Arkansas Bd. of Corrections, 505 F.2d 194 (8th Cir. 1974); Gates v. Collier, 501 F.2d 1291 (5th Cir. 1974); Holt v. Sarver, 309 F. Supp. 362 (E.D. Ark. 1970), affd, 442 F.2d 304 (8th Cir. 1971).

84 Argersinger v. Hamlin, 407 U.S. 25, 48 (1972). Jail conditions have been found to violate "basic standards of human decency, not some mere gastideous squeamishness or private sentimentalism." Brenaman v. Hadigan, 343 F. Supp. 128, 133 (N.D. Cal. 1972). Local jail conditions have raised serious eighth amendment constitutional questions, M. HermaAN, Prisoners Rugets Sourceboor 114-15 (1973), and have been the subject of class action suits attempting to rectify these conditions. See, e.g., Wayme County Jail Inmates v. Lucas, 391 Mich. 359, 216 N.W.2d 910 (1974).

85 See R. Clarro, Crmae in Alaeruca 216 (1970). In a report on the rehabilitative services available to the lower courts, the National Council on Crime and Delinquency surveyed 250 counties in 50 states, excluding institutions in which offenders were kept less than 30 days. The survey showed that institutions average one psychologist for 4,282 inmates, one vocational teacher for every 1,031 inmates, one academic teacher for 1,333 inmates, one psychiatrist for every 2,436 inmates, one social worker for every 846 inmates, and one custodial officer for nine inmates. Of these officers, $51.7 \%$ were paid $\$ 5,000$ a year or less starting salary, and another $25.3 \%$ were paid a starting salary of between $\$ 5,001$ and $\$ 6,000$ a year. National Council on Crime and Delinquency, Correction in the United States, in 13 Crane and Delinquency 142, 145 (1967).

86 See AxIERICAN Bar Association in conjunction with AMERTCAN MEDICAX Association, Medical and Health Care in Jams, Prisons and Otmen Correc-

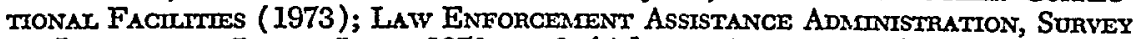
of Inaxates of Local JaILs, 1972, at 8 (Advance Report 1974). Seven out of eight of the jails surveyed had no medical facilities.

87 See, e.g., Woodhous v. Virginia, 487 F.2d 889 (8th Cir. 1973); Pugh v. Locke, 406 F. Supp. 318 (M.D. Ala. 1976); Van Horn v. Lukhard, 302 F. Supp. 384 (E.D. Va. 1975).

88 See R. Goldfarb, Jails: The Ultonate Geetto, 105-12, 124-25, 286, 300-01 (1975).

89 Argersinger v. Hamlin, 407 U.S. 25, 37 n.6 (1972).

90 See Platt, An Odd Couple, The Criminal Sanction and the Municipal Ordinance, 7 WIILARIETTE L.J. 43, 59 (1971). 
Lessons learned in the "school of crime" ${ }^{91}$ may make a defendant more likely to commit additional, more serious, crimes in the future.

Not all misdemeanor convictions result in jail terms, however. A common sentence for a misdemeanor conviction is a fine ${ }^{92}$ which may be significant. ${ }^{93}$ In addition to the obvious financial burden, a defendant's inability or refusal to pay a fine may result in a jail sentence. ${ }^{94}$ In addition to a fine or incarceration, other direct criminal consequences of conviction may include the imposition of stringent conditions of probation for a period of years, ${ }^{95}$ and more serious punishment for a subsequent offense. ${ }^{96}$

Indirect civil consequences ${ }^{97}$ of misdemeanor convictions include the loss of driving privileges ${ }^{98}$ and disqualification for licensed professions.99 Considerable stigma also may be attached to some misdemeanor convictions, ${ }^{100}$ regardless of the sentence received. The stigma of dishonesty, violence, or moral depravity may do incalculable damage to a person's reputation. Even with relatively non-stigmatizing offenses, the fact that the charge appears on police records, which may be furnished to prospective employers, is a significant disability.

91 See Flynn, Jails and Criminal Justice, in Prisoners IN AMERraA (L. Ohlin ed. 1973); R. Crark, CrRane in Amertca 216 (1970).

92 Lower courts have a reputation of being revenue producers, with an emphasis on profits, not justice. The slogan "Let the cash registers ring with justice" demonstrates the point. Rossum, Problems in Municipal Court Administration and the Stress of Supreme Court Decisions: A Memphis Case Study, 3 AM. J. Crnm. L. 53, 71 (1974).

93 Many "petty" offenses are punishable by a fine of up to $\$ 500$, see 18 U.S.C. $\$ 1$ (1970), an amount that can hardly be described as de minimus.

94: A fine will have little beneficial effect if it is levied on an individual who does not have the ability to pay. A large proportion of offenders confined in local jails are there for non-payment of fines." NATIONAL ADvisory CoMmission on Crmmnat Justice Standards and Goats, Corrections 163 (1973).

95 See Note, Limitations Upon Trial Court Discretion in Imposing Conditions of Probation, 8 GA. L. Rev. (1974). Michigan, for example, permits the imposition of two years of probation for a misdemeanor which has a maximum incarceration of 90 days. Mich. CoMp. Laws ANv. \$771.2 (1967).

${ }^{96}$ See, e.g., MicE. CoMp. LAws ANN. $\$ 257.625,257.625$ (b) (1976).

${ }^{97}$ See Note, Limiting Judicial Incompetence: The Due Process Right to a Legally Learned Judge in State Minor Court Criminal Proceedings, 61 VA. L. Rev. 1454, 1489 n.201 (1975); Special Project, The Collateral Consequences of a Criminal Conviction, 23 VAND. L. REv. 929 (1970).

98 E.g., Mich. CoMrp. LAws ANN. $\$ 257.319$ (1976).

99 E.g., Mran. CoMp. Laws ANN. $\$ \$ 338.1812,750.428$ (1967) (physicians and surgeons); see Argersinger v. Hamlin, 407 U.S. 25, 48 n.11 (1972) (Powell, J., concurring). See generally Bromberger, Rehabilitation and Occtpational Licensing: A Conflict of Interests, 13 WM. \& MARY L. Rev. 794 (1972).

100 District of Columbia v. Clawans, 300 U.S. 617 (1937); James v. Hedley, 410 F.2d 334 (5th Cir, 1969). See Taylor, The Supreme Court, the Individual, and the Criminal Process, I GA. L. Rev. 386, 434 (1967). 
Furthermore, although misdemeanors involve a shorter maximum incarceration than felonies they are not necessarily less complex and therefore less deserving of protection for defendants so charged. Crimes are classified by the degree of social harm rather than by the complexity of proof; therefore, the evidence required for some misdemeanor convictions may be as complex as for felony convictions. In fact, thirty percent of all misdemeanors are simply less serious counterparts of felonies that present legal and factual issues of equal difficulty. ${ }^{101}$ Misdemeanor cases also present no dearth of constitutional issues.

As the Supreme Court noted in Sibron v. New York, 102 "[m]any deep and abiding constitutional problems are encountered primarily at the level of 'low visibility' in the criminal process in the context that prosecutions are 'minor offenses' which carry only short sentences." 103 Certainly the forty percent of all misdemeanors referred to as "social nuisance" offenses 104 can present substantial issues and may "often bristle with thorny constitutional questions." 105

The complexity of misdemeanor cases is further illustrated by the degree to which the conduct resulting in misdemeanor prosecution is subject to discretionary interpretations by the police and prosecutors, ${ }^{108}$ even though constitutionally protected activity is often involved. ${ }^{107}$ Police investigative functions in the misdemeanor area may lead to constitutional violations. Although only a small percentage of misdemeanor cases are appealed, ${ }^{108}$ numerous misdemeanor cases do reach the Supreme Court. ${ }^{109}$ The fact that mis-

101 Courrs, supra note 2, at 55 (referring to simple assault and petty larceny). 102392 U.S. 41 (1968).

103 Id. 52.

104 Courts, supra note 2 , at 55.

105 Argersinger v. Hamlin, 407 U.S. 25, 33 (1972).

106 See genetally K. Davis, Pource Discretion (1975); K. Davis, DiscretionARx Justice: A Premininary Ingumy (1969).

107 See, e.g., Papachristou v. City of Jacksonville, 405 U.S. 156 (1972).

108 See Note, The De Novo Procedure-Assessment of Its Constitutionality Under the Sixth Amendment Right to Trial by Jury and the Due Process Clause of the Fourteenth Amendment, 55 Boston U.L. Rev. 25, 51 (1975) (in 1973 a little more than one percent of the people convicted in Massachusetts lower courts appealed to a trial de novo); S. BING \& S. Rosenfeld, The Quaritry of Justice in the Lower Criminal Coutts of Metroporiran Boston 97 (1970) (in 1968, 20\% appealed in Boston). Cf. Mileski, Courtroom Encounters: An Observation of a Lower Criminal Court, 5 LAw \& Soc'y Rev. 473, 480 (1971) ("One possible explanation of why so few misdemeanor convictions are appealed is that many misdemeanants do not know they have a right to appeal." Id.).

109 E.g., North v. Russell, 427 U.S. 328 (1976); City of New Orleans v. Dukes, 427 U.S. 297 (1976); Vachon v. New Hampshire, 414 U.S. 478 (1974); Ward v. City of Monroeville, 409 U.S. 57 (1972); Argersinger v. Hamlin, 407 U.S. 25 (1972); 
demeanors appear to be disproportionately underrepresented in appellate courts is probably due to the misdemeanant's inability to get his case to the appellate court rather than the absence of important issues.

Despite the seriousness and complexity of misdemeanor charges, the legal procedures employed in misdemeanor and felony courts and the training and competence of those who employ them differ significantly. A defendant charged with a misdemeanor receives fewer procedural protections in every step of the criminal process. His case receives less judicial scrutiny and therefore less verification of his guilt than that of the accused felon. Case investigation tends to be minimal or nonexistent because the police and prosecutors are overburdened with felony cases. In some jurisdictions police officers have full.discretion to charge a person with a misdemeanor; ${ }^{110}$ as a result, an individual may be accused of a crime and required to appear in court before any person with legal training reviews his case. Inside the courthouse, the distinction remains. Both the prosecutor and the defense attorney, when they are used, may be relatively inexperienced, ${ }^{111}$ and the lower court judge may be a lay person with no legal training. ${ }^{112}$ In addition to the minimal training and experience of personnel who process misdemeanor cases, there are fewer screening procedures to weed out cases where the defendant either should not have been charged or where his case should have been dismissed at a pretrial stage. There is no grand

Colten v. Kentucky, 407 U.S. 104 (1972); Shadwick v. Tampa, 407 U.S. 345 (1972); Gooding v. Wilson, 405 U.S. 518 (1972); Papachristou v. City of Jacksonville, 405 U.S. 156 (1972); Mayer v. City of Chicago, 404 U.S. 189 (1971); Coates v. Cincinnati, 402 U.S. 611 (1971); Tate v. Short, 401 U.S. 395 (1971); Groppi v. Wisconsin, 400 U.S. 505 (1971); Baldwin v. New York, 399 U.S. 66 (1970); Williams v. Illinois, 399 U.S. 235 (1970); Sibron v. New York, 392 U.S. 40 (1968); Schmerber v. Califomia, 385 U.S. 757 (1966); Shuttlesworth v. Birmingham, 382 U.S. 87 (1965); Hamm v. Rock Hill, 379 U.S. 306 (1964); Bouie v. City of Columbia, 378 U.S. 347 (1964); Thompson v. City of Louisville, 362 U.S. 199 (1960); District of Columbia v. Clawans, 300 U.S. 617 (1937); Tumey v. Ohio, 273 U.S. 510 (1927); Counselman v. Hitchcock, 142 U.S. 547 (1892).

110 F. Mmter, Prosecurron 9-10 (1970); Oaks \& Lehman, The Criminal Process of Cook County and the Indigent Defendant, 1966 U. Ir.. L.F. 584, 608-10; cf. Note, The Municipal Court Misdemeanor Arraignment Procedure of Hamilton County, Ohio: An Empirical Study, 41 U. CINN. L. Rev. 623, 635 (1972) (court clerks issue charges -without judicial approval).

111 Misdemeanor public defenders are frequently new lawyers or candidates for admission to the state bar. Misdemeanants are also represented by students practicing under student practice rules. S. Krantz, C. Smiri, D. Rossman, P. Froyd \& J. Hofmaman, Rught to Counsel in Craminal Cases 165 (1976) Thereinafter cited as S. Krantz]. Police officers act as prosecutors in some jurisdictions for misdemeanor offenses. S. BING \& S. RosenFEID, supra note 108, at 29; CourTs, supra note 2, at 30 .

112 See North v. Russell, 427 U.S. 328, 333 n.4 (1976). 
jury ${ }^{113}$ or preliminary examination. ${ }^{114}$ Additionally, there is little or no motion practice, ${ }^{115}$ and whatever discovery procedures exist are mainly informal.116 In some jurisdictions a defendant is expected to plead or stand trial on the same day as the initial arraignment. ${ }^{117}$ Trials are often much speedier for misdemeanors. ${ }^{118}$ Frequently sentencing immediately follows conviction; as a result, presentence reports are seldom prepared.119

The procedural disparities between felony and misdemeanor administration are not mitigated by greater consultation between the misdemeanor defendant and his attorney. Although all indigents charged with felonies have the right to court-appointed counsel, ${ }^{120}$ only some indigents charged with misdemeanors share that right. Argersinger $v$. Hamlin ${ }^{121}$ extended the right to counsel to an indigent misdemeanant who is sentenced to jail. ${ }^{122}$ Because incarceration is not the most frequently imposed sanction, however, most indigents charged with misdemeanors need not be offered counsel..$^{123}$

Differences in the procedures for appointment of counsel further exacerbate the distinctions in the sixth amendment right to counsel depending on whether the charge is a felony or misdemeanor. Felony courts routinely appoint counsel, whereas misdemeanor courts merely offer counsel. The difference is substantial. Virtually all eligible accused felons receive assistance of counsel, but many eligible accused misdemeanants do not. The manner in

113 Indictment is not required, at least in federal practice, for misdemeanors punishable by fine or local jail confinement. See Duke v. United States, 301 U.S. 492 (1937).

114 See FED. R. CRRr. P. 5(c).

115 Rougr Justice, supra note 33 , at $\mathrm{xxv}$; see S. BING \& S. ROSENFEnd, supra note 108, at 78-79 ( 10 written motions in 2,000 cases).

116 See Discovery in Criminal Cases: Denial to Misdemeanants as a Violation of Due Process and Equal Protection, 65 J. Crms. L. \& CRm. 181 (1974).

117 See Counts, supra note 2, at 30; Note, supra note 110, at 623.

118 See Dash, Cracks in the Foundation of Criminal Justice, 46 Ir. L. Rev. 385 (1951).

110 Courts, supra note 2, at 31; S. KRANTz, supra note 111, at 184; Platt, An odd Couple: The Criminal Sanction and the Municipal Ordinance, 7 Wricasetre L.J. 43,56 (197I).

120 Gideon v. Wainwright, 372 U.S. 335 (1963).

121407 U.S. 25 (1972).

122 Id. 37. The Supreme Court expressed the right in the negative: "We hold, therefore, that absent a knowing and intelligent waiver, no person may be imprisoned for any offense, whether classified as petty, misdemeanor, or felony, unless he was represented by counsel at his trial." Id. No jurisdiction apparently has attempted to distinguish the plea stage from trial.

123 Some courts, however, such as the Misdemeanor Division of Detroit Recorder's Court, offer counsel to every indigent without a prior determination whether incarceration is a likely disposition. 
which the offer is made becomes crucial. The predisposition of the offeree and differences-either conscious or unconscious-in the manner of delivering the offer result in far fewer eligible misdemeanants. accepting counsel than the number so entitled. ${ }^{124}$

Even where counsel is present, the protections afforded defendants are not as great as imagined. ${ }^{225}$ In the past the presence of counsel created the assumptions that the criminal process was fair, ${ }^{126}$ and that a guilty plea was truthful, based on consent, and entered with an awareness of the consequences. ${ }^{127}$ These assumptions are no longer held in the federal courts, however, as evidenced by the stringent mandate of rule 11 . It is equally unfounded in state courts as to guilty pleas in misdemeanor cases. Attorneys who represent misdemeanants have far more clients, and consequently must spend less time per client, than those who represent felons. ${ }^{128}$ A high client-attorney ratio is the rule for both the public defender and the private attorney. The economics of the system demands this higher ratio to obtain more representation in dollar terms from the salaried public defender. Private attorneys also find that the high ratio enables them to run supermarket style law offices-high volume, quick turnover, and low margin. ${ }^{129}$ Lawyers hardly spend the time to learn their clients' names, much less discuss constitutional rights and defenses. This abbreviated lawyer-client rela-

124 See S. Krantz, supra note 111 , at 381 ; L. SmVErstem, Defense of the Poor in Crumunal Cases in American State Courts 89 (1965); Mileski, supta note 108 , at 482,484 .

125 See Ingraham, The Impact of Argersinger-One Year Later, 8 LAw \& Soc'Y Rev. 615, 623 (1974); Junker, The Right to Counsel in Misdemeanor Cases, 43 WASH. L. REv. 685, 699 (1968). In fact, a person charged with a misdemeanor may be better off without counsel. One study has shown that defendants who waive counsel receive more lenient treatment than those who insist upon the assignment of counsel. See S. BING \& S. RosenFend, supra note 108, at' 53 (defendants without counsel are found not guilty more often and, if found guilty, receive a fine rather than a jail sentence more often than defendants with counsel).

126 See 97 A.L.R.2d 549 (1964); D. NEWMAN, supra note 2, at 226-27.

127 D. NETMMAN, supra note 2 , at $51,200$.

128 Full-time defenders average 483 misdemeanor cases per year. Natronar Legai Am and Defender Association, The Other Face of Justice 29 (1973). The recommended caseload maximum is 400 misdemeanors per year, or 150 felonies. Nationat Advisory Comantsion on Crmmnar. Justice Standards and Goals, Courts 276 (1973). Defenders reported, on an average, that they thought only 295 misdemeanor defendants, or 140 felony defendants, can be effectively represented by a single, full-time attorney. See generally Comment, Caseload Ceilings on Indigent Defense Systems to Insure Effective Assistance of Counsel, $43 \mathrm{U}$. CinN. L. REv. 185 (1974).

129 Bazelon, The Defective Assistance of Counsel, 42 U. CnNv. L. Rev. 1, 9-11 (1973). A plea of guilty may be as remunerative for the defense lawyer as a full day of trial. In Michigan appointed counsel is paid $\$ 100$ for a full day of trial and $\$ 100$ for a guilty plea. Rule 14.13, Rules of the Circuit Court for the County of Wayne, in Michigan Gen. Cr. RuLes. 
tionship, frequently occurring under circumstances where a defendant is assumed to be guilty, ${ }^{130}$ results in a mass-produced system of justice that encourages a defendant to plead guilty.

Under present practices a defendant who pleads guilty to a misdemeanor charge can be convicted without any verification of guilt by someone with the legal expertise to do so. As a result, the ultimate determination of whether a crime has been committed is made by the defendant or the defense counsel rather than by the court. The defendant, who has an obvious interest in not subjecting himself to punishment, does not have the legal expertise to make that determination; the defense counsel, who may have adequate legal expertise, frequently does not share that interest. ${ }^{131}$ For many reasons the defense counsel may owe greater allegiance to the bureaucratic structure of the lower court than to his own client. ${ }^{132}$ Participation in fewer trials may be economically advantageous to him, ${ }^{133}$ or perhaps reduce his conflicts with the enforcement system of which he has become a quasi-member. This misplaced loyalty may cause a defense attorney to persuade his client to offer a plea, although a trial would be a defendant's better course of action. ${ }^{134}$

The creation of misdemeanor public defender offices will not necessarily provide more effective protection for defendants. Surprisingly, public defenders seem to enter guilty pleas at approximately the same rate as private attorneys. ${ }^{135}$ Some defenders even tend to exalt their ability to procure pleas. ${ }^{136}$ Although defender offices would seem to be most resistant to pressures exerted by

130 See Skolnick, Social Control in the Adversary System, II J. of Confurct Resolumion 52, 62 (1967); Sudnow, Normal Crimes: Sociological Features of the Penal Code in a Public Defender Office, 12 Social Problems 225 (1964).

131 To say that a defendant's lawyer may not share that defendant's interest in acquittal runs counter to a central hypothesis of the adversary system. It is generally assumed that a lawyer's interest is with his client, not with the court, nor with opposing counsel. It is further assumed that the lawyer only allows his client to offer a plea when the lawyer believes the plea to be in the client's best interest. Although a defense attorney should zealously represent his client, because of bureaucratic pressures, "able, conscientious and highly motivated attorneys . . make decisions that are not in their clients' interests." Alschuler, The Defense Attorney's Role in Plea Bargaining, 84 Yale L.J. 1179, 1180 (1975).

132 Blumberg, Covert Contingencies in the Right to the Assistance of Counsel, 20 VAND. L. REv. 581, 587-88 (1967).

133 The Supreme Court, 1969 Term, 84 HaRv. L. Rev. 148, 152 (1970).

134 Blumberg, supra note 132 , at 602 . "Of course, the defense attorney's inclination to offer a plea, which may be in opposition to the defendant's best interest, is never communicated directly as being the defense attorney's interest. The lawyer attempts to convince the defendant that it is in the defendant's best interest to plead." Id.

135 Alschuler, supra note 131, at 1206.

130 Id. 
enforcement systems, ${ }^{137}$ the creation of defender offices and the resulting improvement of the court system often results in but a more sophisticated apparatus for processing a defendant towards a guilty plea. ${ }^{138}$

Although patient judges with sufficient expertise might be able to compensate for the procedural deficiencies in the lower courts, the present caliber of many of those judges precludes such a result. The integrity of the criminal justice system during the plea process depends upon the judge; ${ }^{139}$ misdemeanor judges frequently do not have the expertise to perform this function. Many states allow lay people to sit as lower court judges. ${ }^{140}$ The Supreme Court recently held that a trial before a lay judge is not a violation of a defendant's rights under the federal constitution if defendants are entitled to a trial de novo before a higher court with a lawyerjudge, ${ }^{141}$ notwithstanding the severe criticism of such courts in contemporary studies. ${ }^{142}$

The procedural disparities in the lower courts have deleterious effects on both an individual and societal level. When a lower court focuses on expediting its docket instead of safeguarding the rights of a defendant, notions of fundamental fairness are violated. Furthermore, the individual's chances of rehabilitation are reduced. Although the greatest opportunity for diverting a person from a career of crime and revolving-door appearances in court occurs at the individual's first contact with the law-usually a misdemeanor proceeding ${ }^{143}$-the current caliber of lower courts does little to foster that goal.- As the President's Commission on Law Enforcement and Administration of Justice observed, "[t] he many persons who encounter these courts each year can hardly fail to interpret the experience as an expression of indifference to their situations and the ideals of fairness, equality, and rehabilitation professed in theory." 144

On a societal level, the importance of misdemeanor cases lies in their magnitude; approximately four to five million misdemeanor

137 Junker, supra note 125, at 702.

138 See Blumberg, supra note 132, at 605.

139 See D. NEWMAN, supra note 2, at 235; The Supreme Court, 1969 Term, 84 HARv. L. REv. 148, 152 (1970).

140 North v. Russell, 427 U.S. 328,333 n.4 (1976).

141 Id. 339.

142 See id. 340 n.2 \& studies cited therein (Stewart, J., dissenting).

143 Counts, supra note 2 , at 29.

$144 I d$. 
cases occur each year, exclusive of traffic offenses. ${ }^{145}$ More people receive firsthand information about the criminal justice system in the misdemeanor court than in any other forum. ${ }^{146}$ Current misdemeanor procedures are detrimental to the image and integrity of the criminal process. "[A] system that treats the defendants who are charged with minor offenses with less dignity and consideration than it treats those who are charged with serious crimes is hard to justify." 147

One method to ameliorate the situation in the misdemeanor courts would be the institution of an accuracy requirement for all guilty pleas. Before turning to a proposal for an accuracy inquiry applicable to guilty pleas in both felonies and misdemeanors, the development of the accuracy inquiry and the current state of the law regarding it will be suryeyed.

\section{Development of the ACcuracy InQuiry}

\section{A. Evolution}

Prior to 1966 inquiries regarding the accuracy of guilty pleas were made by certain judges in both state and federal courts. ${ }^{148}$ The question whether a factual basis should be required for a valid plea of guilty or nolo contendere did not attract much attention, however, until 1966 when a factual basis became mandatory for pleas of guilty in federal courts through an amendment to rule 11 of the Federal Rules of Criminal Procedure. ${ }^{149}$ After three

I45 Id. 29, 47, 55; Report of the Conference of Legal Manpower Needs of Criminal Law, 41 F.R.D. 389, 392 (1966).

146 It is estimated that $90 \%$ of the criminal cases in this country are misdemeanors. Courss, supra note 2 , at 29.

147 Chatrenge of Crane, supra note 75, at 129.

148 See Note, Revised Federal Rule 11: Tighter Guidelines for Pleas in Criminal Cases, 44 FondhaM L. Rev. 1010, 1021 n.96 (1976); Note, The Trial Judge's Satisfaction as to the Factual Basis of Guilty Pleas, 1966 WASH. U.L.Q. 306, 308-19. 149 Prior to 1966 , rule 11 provided:

A defendant may plead not guilty, guilty or, with the consent of the court, nolo contendere. The court may refuse to accept a plea of guilty, and shall not accept the plea without first determining that the plea is made voluntarily with understanding of the nature of the charge. If a defendant refuses to plead or if the court refuses to accept a plea of guilty or if a defendant corporation fails to appear, the court shall enter a plea of not guilty.

As amended in 1966, the rule provided:

A defendant may plead not guilty, guilty or, with the consent of the court, nolo contendere. The court may refuse to accept a plea of guilty, and shall not accept such plea or a plea of nolo contendere without first addressing the defendant personally and determining that the plea is made voluntarily with understanding of the nature of the charge and the conse- 
years of lower federal court experience with the rule, the Supreme Court first addressed the factual basis issue in McCarthy $v$. United States. ${ }^{150}$ In McCarthy the Court discussed the relationship between voluntariness and the factual basis determination, ${ }^{151}$ emphasizing the protective function performed by the factual basis requirement. ${ }^{152}$ The factual basis issue, however, was not discussed in the context of McCarthy's case. ${ }^{153}$ Instead the Court, acting under its supervisory power over the lower federal courts, ${ }^{154}$ held that McCarthy should be afforded an opportunity to plead anew because the trial judge's noncompliance with rule 11 deprived him of "the Rule's procedural safeguards that are designed to facilitate a more accurate determination of the voluntariness of his plea." 155 The trial court judge had failed to address McCarthy personally and to inquire whether he understood the nature of the charge and was aware of the consequences of his plea. The Court did indicate, however, that the voluntariness and factual basis requirements are inextricably linked, finding that a guilty plea "cannot be truly voluntary unless the defendant possesses an understanding of the law in relation to the facts." ${ }^{158}$ The Court interpreted rule 11 to re-

quences of the plea. If a defendant refuses to plead or if the court refuses to accept a plea of guilty or if a defendant corporation fails to appear, the court shall enter a plea of not guilty. The court shall not enter a judgment upon a plea of guilty unless it is satisfied that there is a factual basis for the plea.

$\therefore$ The 1966 amendment added the conditions that the judge personally address the defendant, include the defendant's understanding of the consequences' of the plea as an element in determining voluntariness, and be satisfied that a factual basis for the plea existed. For the present version of the rule regarding accuracy, see note 5 supra.

150394 U.S. 459 (1969).

151 Id: 466.

152 Id. 467.

153 The Court noted that

The Government agrees with the Court of Appeals that the record of the September 14 sentencing hearing demonstrates that the District Judge satisfied himself by examining the presentence report that there was a factual basis for the plea. However, because of the Government's concession at oral argument that the judge did not inquire whether petitioner understood the nature of the charge, and because of our holding that any noncompliance with Rule 11 is reversible error, we need not consider the Government's contention that the record adequately supports the Court of Appeals' conclusion that the district judge satisfied himself that there was a factual basis for the plea.

Id. 464 n.9.

154 Id. 464.

155 Id. $471-72$.

${ }^{156} \mathrm{Id}$. 466 (footnote omitted). This language and subsequent interpretations of Boykin v. Alabama, 395 U.S. 238 (1969), and North Carolina v. Alford, 400 U.S. 25 (1970), have become the basis for the argument that a factual basis inquiry is an element of due process and therefore is a federal constitutional requirement 
quire not only that a judge personally inquire whether a defendant understands the nature of the charge against him and whether he is aware of the consequences of his plea, but also that a judge personally ascertain whether a factual basis for the plea exists in order for the plea to be valid. ${ }^{157}$

Although none of the constitutional arguments were reached in $M c$ Carthy, ${ }^{158}$ the decision had widespread impact in both federal and state courts. Bound by the Supreme Court's supervisory power, federal judges were required to accept pleas in a manner that would insure the existence of a factual basis for each guilty plea. Reacting to the substance of this policy decision by the Court, a majority of the states reformed their plea procedures by adding a factual basis requirement. ${ }^{159}$

In the year following McCarthy, the Court decided whether a state court could accept a plea of guilty when the pleader proclaimed his innocence in North Carolina v. Alford. ${ }^{160}$ The Court reasoned that

while most pleas of guilty consist of both a waiver of trial and an express admission of guilt, the latter element is not a constitutional requisite to the imposition of criminal penalty. An individual accused of crime may voluntarily, knowingly, and understandingly consent to the imposition of a prison sentence even if he is unwilling or unable to admit his participation in the acts constituting the crime. ${ }^{161}$

The Court held that it is not constitutional error for a court to accept a guilty plea containing a protestation of innocence if the defendant intelligently concludes that his interests require the entry

for a valid plea. See Heberling, Judicial Review of the Guilty Plea, 7 IrnconN L. Rev. 137, 181-83 (1972); The Supreme Coutt, 1968 Term, 83 Harv. L. Rev. 7, 184-85 (1969). Although such a conclusion would lead to one goal of the proposed accuracy standard-application of the accuracy inquiry in all jurisdictions for all types of crimes-it would still fail to resolve questions concerning the appropriate form for the accuracy inquiry. Although finding the constitutional argument quite persuasive, this Article bases its proposal on broad policy arguments applicable regardless of the constitutional necessity of an accuracy inquiry.

157394 U.S. at 467.

$158 \mathrm{Id} .464$.

159 See note 6 supra.

160400 U.S. 25 (1970). Harry Alford was charged with first-degree murder and, following a conviction by trial, would be punished by death under the existing North Carolina law unless the jury recommended that the punishment be life imprisonment. Alford pleaded guilty to the lesser included offense of second-degree murder and thereby was eligible for, and received, the maximum penalty of thirty years' imprisonment. For Alford's tender of his guilty plea and protestation of innocence, see id. 28 n.2.

161 Id. 37. 
of the plea, ${ }^{162}$ and if the record before the judge contains a "strong factual basis" for the plea. ${ }^{163}$ The Court thus permitted; but did not require, the states to accept pleas from defendants who claim innocence when a strong factual basis for the plea is established. ${ }^{164}$ The states were thus allowed to develop their own rules whether to accept such pleas, ${ }^{165}$ and many have since done so. ${ }^{166}$

McCarthy and Alford lay a foundation for the development of accuracy inquiry procedures by underlining the purpose of the factual basis requirement and by setting the threshold for, when it is invoked: a factual basis is required for all pleas of guilty in federal courts and for pleas of guilty in state courts when the defendant protests his innocence; the Court has not required a factual basis for state pleas when the defendant admits guilt. The task of developing the parameters for the accuracy inquiry has been left to the states and lower federal courts.

\section{B. Resistance}

Many jurisdictions still do. not require a factual basis for a valid felony plea. The stated and unstated reasons for the failure to institute such a procedure include problems inherent in negotiated pleas, time constraints, and judicial attitudes.

During plea negotiations ${ }^{107}$ the prosecution and the defense may strike many types of bargains. ${ }^{168}$ The defendant may plead to

162 Id.

163 Id. 38.

$104 C f$. id. 38 n.10 (implying that federal courts may accept guilty pleas that are accompanied by protestations of innocence as long as rule 11 's factual basis requirement is met).

165 Id. 38 n.11.

160 See, e.g., State v. Dixon, 111 Ariz. 92, 523 P.2d 789 (1974); Robinson v. State, 291 A.2d 279 (Del. 1972); People v. Hudson, 7 Ill. App. 3d 800, 288 N.E.2d 533 (1972).

167 In some circumstances plea negotiations are tacit, rather than overt. In tacit plea bargaining the defendant relies upon the unstated assumption that the judge will sentence a defendant who pleads guilty more leniently than he would were the same defendant convicted at trial. Many judges admit that they consider the defendant's plea when deciding what sentence to impose, Note, Plea Bargaining: The Judicial Merry-Go-Round, 10 DoQ. L. Rev. 253, 255 (1971), and an" empirical study conducted by the Yale University Law Joumal confirms this practice. Note, The Influence of the Defendant's Plea on Judicial Determination of Sentence, 66 YALE L.J. 204, 206-209 (1956).

168 A "bargain" exists only when it involves actual or apparent advantages to both parties. Prosecutors bargain to save the time and expense attendant on trials; defendants bargain for (1) reduced charges, (2) less severe sentences, (3) conviction of fewer offenses, or (4) avoidance of the stigma attaching to conviction of certain classes of crimes, particularly sexual 
the crime as charged, ${ }^{160}$ to one of several original counts, ${ }^{170}$ to an added charge, ${ }^{171}$ or to a lesser included offense. ${ }^{172}$ The establishment of a factual basis can be more difficult, if not impossible, when the defendant pleads to a crime not encompassed in the original charge; ${ }^{173}$ consequently, some states do not require a factual basis for negotiated pleas. ${ }^{174}$ Other states, however, require a factual basis even for negotiated pleas. ${ }^{175}$ The argument for not requiring a factual basis for negotiated pleas is superficially appealing when the charge to which the defendant pleads guilty is a hypothetical ${ }^{170}$ or real ${ }^{177}$ crime that the defendant did not commit. A truthful factual basis could not be established for such a plea. The negotiated plea may have been selected only because of its sentencing

offenses. Although these considerations can be theoretically separated, in practice they are dependent and interrelated.

F. MmLer, Prosecution 192 (1970) (footnotes omitted).

[T] here are four possible concessions that may be made in a plea agreement. First, the charge may be reduced to a lesser or related offense. Second, the attorney for the government may promise to move for dismissal of other charges. Third, the attorney for the government may agree to recommend or not oppose the imposition of a particular sentence. Fourth, the attorneys for the government and the defense may agree that a given sentence is an appropriate disposition of the case.

Advisory Committee Notes to FED. R. CRrM. P. 11 (1975).

169 Such a plea is colloquially referred to as a plea "on the nose." F. Mrr.rer, supra note 168, at 193.

$170 \mathrm{~A}$ defendant might plead to one of the original charges in exchange for dismissal of one or more other counts. See State v. LeGear, $187 \mathrm{Neb} .763,193$ N.W.2d 763 (1972).

171 Added offenses, by definition, have different elements of proof than the original charge.

172 Generally, lesser included offenses share some, but not all, elements of the original offense. See Koenig, The Many-Headed Hydra of Lesser Included Offenses: A Herculean Task for the Michigan Courts, 1975 DEr. C.L. Rev. 41.

173 Obviously any difference in the elements between the original charge and the negotiated plea will not disrupt the accuracy inquiry if a defendant has also committed the lesser included or added offense.

174 See, e.g., People v. Clairborne, 29 N.Y.2d 950, 280 N.E.2d 366, 329 N.Y.S.2d 580 (1972); Wilson v. State, 57 Wis. $2 d$ 508, 204 N.W.2d 508 (1973).

175 See, e.g., People v. Spicer, 10 III. App. 3d 390, 294 N.E.2d 72 (1973); People v. Troyan, 21 Ill. App. 3d 375, 315 N.E.2d 335 (1974). Cf. State v. Gustafson, 298 Minn. 200, 214 N.W.2d 341 (1974) (factual basis must exist for crime at least as serious as one to which defendant is willing to plead).

$176 \mathrm{~A}$ crime may be hypothetical in the sense that it may be theoretically impossible for any person to commit such a crime. The use of attempt statutes to make charge reductions for plea bargaining purposes can create hypothetical crimes when the specific intent required for the attempt is combined with a crime that only requires a general intent. See People v. Griffin, 7 N.Y.2d 511, 166 N.E.2d 684, 199 N.Y.S.2d 674 (1960) (attempted assault); People v. Foster, 19 N.Y.2d 150, 225 N.E.2d 200, 288 N.Y.S.2d 603 (1967) (attempted manslaughter).

177 A real crime is one that is theoretically possible for a person to commit. 
provision, ${ }^{178}$ without consideration of whether the crime is capable of being committed or whether the defendant actually committed it. A factual basis requirement would eliminate these negotiated pleas that have no basis in fact and thereby assure a defendant of needed protections. Although the ABA Plea Standards implicitly approve the procedure whereby a defendant pleads to either a hypothetical crime or a crime that he did not commit, ${ }^{179}$ the innocent pleader does exist and is entitled to protection. The preferable approach would be to select carefully a negotiated plea charge for which the defendant could provide a truthful factual basis and which has a satisfactory penalty provision. ${ }^{180}$ Alternatively, the defendant could be permited to engage in sentence bargaining while pleading to the original charge. ${ }^{181}$

Another reason given for eliminating the factual basis for negotiated pleas is that a defendant pleading guilty to a negotiated plea is fully cognizant of the facts and believes the evidence against him to be sufficient to prove his guilt. ${ }^{182}$ The Supreme Court acknowledged the potential fallacy of such an assumption, however,

178 "Certainly the literature on plea negotiations indicates clearly that almost all defendants in fact bargain for the least sentence possible, and therefore shop for a category of crime which will leave them subject to the range of punishment which they believe will benefit them." George, Lesser Included Offenses in Michigan, 1975 DEr. C.L. Rev. 35, 36 (1975). For a discussion of sentence bargaining, see People v. Byrd, 12 Mich. App. 186, 162 N.W.2d 777 (1968) (Levin, J., concurring). Effective sentence bargaining usually requires the participation of the judge. Judicial participation in plea bargaining, however, is disapproved. See ABA PLEA STANDARDS, supra note 2, at $\$ 3.3(\mathrm{a})$. FED. R. CRm. P. $11(\mathrm{e})(1)$ forbids such judicial participation.

\section{See ABA Plea. Standards, supta note 2, at \$ 3.1 .}

180 Revised criminal codes with degree gradations for crimes can facilitate plea negotiations because they offer greater control over the outside limits of punishment. George, A Guide to State Criminal Gode Revision, in Studies IN Comparattve Crminar Law 70 (E. Wise \& G. Mueller eds. 1975).

181 If judges were required to ascertain a factual basis for all pleas, the reasons that currently prevent them from engaging in sentence bargaining would not be compelling. Judicial participation in negotiation as to pleas and sentences is currently disfavored because of the fear of coercing an innocent defendant to plead guilty. See note 178 supra. If a factual basis for a plea had to be determined on the record, however, a factually innocent defendant could not be coerced into pleading guilty because such a plea could not withstand the scrutiny of an accuracy inquiry. Notwithstanding the proscription on judicial involvement contained in federal rule 1I(e)(1), this Article favors sentence bargaining in those cases where a factual basis is required as a means of providing flexibility without coercion in the negotiation process. Such judicial involvement in plea and sentencing negotiations is condoned in Michigan, for example. The court may agree to certain pleas or sentences as long as that bargaining becomes part of the record. Mrch. GEN. Cr. R. $785.7(4)$. 
recognizing that a defendant who pleads to one of the original charges may not understand that his activity was not criminal.183 A defendant who pleads to a negotiated charge cannot be expected to have any better understanding of the legal process.

Although some courts may believe that the additional time required to make factual basis inquiries would disrupt trial court dockets, that assumption is unfounded. The time expenditure need not be substantial. It has been estimated that a complete voluntariness and accuracy inquiry requires about ten minutes. ${ }^{184}$ In view of the "cursory question and answer sequence" 185 often used to determine voluntariness, this estimate is probably high. In any event, the accuracy inquiry should require only one to two minutes at most. The federal courts have easily accommodated the plea procedures of rule 11 , including the factual basis requirement. There is no reason why other jurisdictions could not have similar experiences.

Judicial indifference to the possibility of an innocent defendant offering a guilty plea may be the ultimate reason for the failure to adopt a factual basis requirement. ${ }^{186}$ Judges may feel either that even the minimal time expenditure that a factual basis inquiry would require is not necessary, ${ }^{187}$ or that defendants do not deserve this additional protection although-as judges know from daily experience-those defendants may not have received competent assistance of counsel. ${ }^{188}$

183 McCarthy v. United States, 394 U.S. 459 (1969).

184 Erickson, Finality of a Plea of Guilty, 48 NoTrE DAME LAw. 835, 848 (1973).

\section{ABA Prea Standaros, supta note 2, at 32.}

186 Some judges have expressed "non-judicial" attitudes regarding the people who appear before them as defendants. See, e.g., Levin, Urban Politics and Judicial Behavior, 1 J. LEGAL STUD. 199 (1972) (judges described defendants as "coming from low intelligence groups," "crummy people," and "congenital criminals"). See generally RovGH JUSTICE, supra note 33.

187 Many judges, of course, do not have this attitude. "Many judges take the position... that the possibility of an innocent person pleading guilty should be given prime consideration in arraignment proceedings." Newman \& NeMoyer, Issues of Propriety in Negotiated Justice, 47 DEN. L.J. 367, 394 (1970).

188 Although a defendant has the right to the effective assistance of counsel at the guilty plea, McMann v. Richardson, 397 U.S. 759 (1970), evaluations of the caliber of counsel are mixed. See Bazelon, The Defective Assistance of Counsel, 42 U. CINN. L. REv. 1 (1973); Craig, The Right to Adequate Representation in the Criminal Process: Some Observations, 22 Sw. L.J. 260 (1968); Finer, Ineffective Assistance of Counsel, 58 CoRner.L L. Rev. 1077 (1973); Kaus \& Mallen, The Misguiding Hand of Counsel-Reflections on "Criminal Malpractice," 21 U.C.L.A. L. Rev. 1191 (1974); Comment, Effective Assistance of Counsel in Plea Bargaining: What Is the Standard?, 12 DuQ. L. Rev. 321 (1973). 


\section{- VI. The Accuracy. Inquiry as Gurrently Applied}

Before advancing a procedure for the accuracy inquiry that should be followed in all courts, a careful look at the procedures presently in use in jurisdictions employing an accuracy inquiry is required. Although federal rule $11(f)$ and the various state sources of the accuracy requirement offer few specific guidelines, an analysis of the relevant case law reveals three concerns on which to base a uniform procedure for the accuracy inquiry to be proposed: 1) the methods used to determine whether a factual basis exists for the plea; 2) the standard of proof required for an adequate factual basis; and, 3) the scope of the inquiry required of a judge in determining the factual basis.

\section{A. Methods}

Three methods of establishing a factual basis for a plea are accepted in all jurisdictions: inquiry of the defendant, inquiry of the prosecutor, or examination of the presentence report. The reaction to other methods has been less than uniform, however.

\section{Federal Courts}

When the factual basis requirement first became part of the Federal Rules of Criminal Procedure, the accompanying Advisory Committee Notes specified that the court could satisfy itself "by inquiry of the defendant or the attorney for the government, or by examining the presentence report, or otherwise, that the conduct which the defendant admits constitutes the offense charged in the indictment or information or an offense included therein to which the defendant has pleaded guilty." 189 The appropriateness and efficacy of the three specified methods of establishing the accuracy of a plea have never been seriously questioned in the federal courts. In fact, they have been implicitly approved by the Supreme Court. ${ }^{190}$ The trial judge, however, is not restricted to these three methods of obtaining information to satisfy the factual basis requirement. The use of the word "otherwise" in the Advisory Committee Notes suggests that other methods may be employed.101 Consequently, a federal judge is "free to utilize any appropriate

189 Advisory Committee Notes to Fed. R. CRmM. P. II (1966).

190 See McCarthy v. United States, 394 U.S. 459, 463 n.6 (1969).

$191^{\prime} \mathrm{Cf}$. id. $467 \mathrm{n} .20$ ("The nature of the inquiry required by Rule 11 must necessarily vary from case to case, and, therefore, we do not establish any general guidelines other than those expressed in the rule itself"). 
procedure which seems best for his court and for the kind of case involved." 192

Because the Supreme Court and rule 11 allow a case-by-case approach in selecting the method of the accuracy inquiry, a personal examination of the defendant by the judge, although mandatory for determination of the voluntariness of the guilty plea, ${ }^{193}$ is not required to establish a factual basis. The court may delegate the duty of questioning an accused to the prosecuting or defense attorney. ${ }^{104}$ Virtually any other source may also contribute to the establishment of a factual basis, including statements of the investigating officer ${ }^{105}$ and other witnesses. ${ }^{196}$ For example, the judge's personal knowledge of a particular defendant's case after having previously presided at a trial of that defendant or of his cofelons, ${ }^{197}$ and the government's case-in-chief when the guilty plea followed presentation of the prosecutor's evidence ${ }^{193}$ have served as the factual basis. In whatever manner the factual basis is determined, the information establishing the plea's accuracy must be incorporated into the record. ${ }^{190}$

Nevertheless, some controversy remains concerning the use of particular methods. One method of doubtful validity is the use of affidavits signed by the defendant. ${ }^{200}$ The Fifth Circuit has re-

192 ABA Plea Standards, supta note 2, at 33.

193 FED. R. CRMM. P. I1(d).

194 Davis v. United States, 470 F.2d 1128, 1131 (3d Cir. 1972) (expressing a preference, however, for questioning by judge).

105 United States v. Clark, 407 F.2d 1336 (4th Cir. 1969).

196 See United States v. Jerry, 487 F.2d 600 (3d Cir. 1973); Gilbert v. United States, 466 F.2d 533 (5th Cir. 1972).

197 See United States v. Maggio, 514 F.2d 80 (5th Cir.), cert. denied, 423 U.S. 1032 (1975); United States v. Kereluk, Nos. 74-1161-62 (6th Cir. May 10, 1974); X v. United States, 454 F.2d 255 (2d Cir. 1971), cert. denied, 406 U.S. 961 (1972). Contra, United States v. Tucker, 425 F.2d 624 (4th Cir. 1970) (presiding over trial of codefendant is not sufficient factual basis if judge is aware of defendant's persistent and repeated assertions of innocence). (1969).

198 Conley v. United States, 407 F.2d 45 (9th Cir.), cert. denied, 396 U.S. 853

199 See Santobello v. New York, 404 U.S. 257, 261 (1971); Manley v. United States, 432 F.2d 1241, 1244 (2d Cir. 1970).

200 Perhaps because of the McCarthy requirement of a personal colloquy between the judge and the defendant to determine the voluntariness of the plea, the signed affdavit is rarely used in federal courts. Most district court judges merely continue this personal examination and ask the defendant whether the actions performed conform to the charge in the indictment. The practical effect of rule 11 thus militates against the use of a signed affidavit. Yet a literal reading of the rule makes clear that the judge is not personally required to address the defendant to determine whether a factual basis exists. 
quired that "the record must reveal a factual basis for the plea in addition to representations such as those made in the affidavit." 201

Another controversial method involves the role of the defense attorney in the accuracy determination. Statements by a defendant's attorney have been allowed as a contributing source of information in determining the factual basis, ${ }^{202}$ as have statements given by a defendant to his attorney which have become part of the record. ${ }^{203}$ The defense attorney, however, must provide the court with more than a generalized admission that a factual basis does exist. ${ }^{204}$

The single greatest controversy in this area in the federal courts involves the practice of reading the indictment to the defendant and then inquiring of him whether he committed the acts in question. The Seventh and Eighth Circuits have ruled that this procedure does not satisfy the factual basis requirement. ${ }^{205}$ Other circuits, however, have been more lenient in accepting pleas when the accuracy determination was made in this manner. ${ }^{206}$

Although the specific factors to be considered in determining the appropriateness of this method have not been clearly identified, some courts have suggested that reading the indictment is not sufficient to establish the factual basis in cases involving more than one defendant, ${ }^{207}$ complex questions of fact or law, ${ }^{208}$ or a defendant who denies his guilt. ${ }^{209}$

\section{State Courts}

Although a few states imposed a factual basis requirement for guilty pleas before the mid-1960's, ${ }^{210}$ most did not act until after accuracy inquiries were mandatory in the federal courts. Because the states are not bound by the federal rules or the McCarthy decision, however, the methods approved therein were not auto-

201 United States v. White, 483 F.2d 7I, 73 (5th Cir. 1973).

202 See Lovelace v. United States, 439 F.2d 784 (6th Cir. 1971).

203 United States v. Rook, 424 F.2d 403, 406 (7th Cir.), cert. denied, 398 U.S. 966 (1970).

204 United States v. Tucker, 425 F.2d 624, 628 (4th Cir. 1970).

205 United States v. Untiedt, 479 F.2d 1265 (8th Cir. 1973); Majko v. United States, 457 F.2d 790 (7th Cir. 1972); United States v. Cody, 438 F.2d 287 (8th Cir. 1971).

206 For example, the Third Circuit in Paradiso v. United States, 482 F.2d 409

(3d Cir. 1973) stated that " $[t]$ he adequacy of reading from the indictment will depend on the facts of the particular case." Id. 415-16 (footnote omitted). 207 United States v. Steele, 413 F.2d 967, 969 (2d Cir. 1969).

208 Jimnez v. United States, 487 F.2d 212 (5th Cir. 1973), cert. denied, 416 U.S. 916 (1974).

200 Dunn v. Casseles, 494 F.2d 397 (2d Cir. 1974).

210 Note 148 supra. 
matically accepted by the states. Therefore, as states addressed the factual basis issue, they had to evaluate the appropriateness of various methods for establishing a factual basis.

The method most frequently used by the states is direct interrogation of a defendant; several state courts have expressed a distinct preference for this approach. ${ }^{211}$ Despite the possibility that the communication process will be distorted to reflect more an examiner's concerns than a defendant's actual knowledge, ${ }^{212}$ only a few courts have discussed the proper form for this colloquy. Typically, a factual basis is not adequately established by a simple inquiry as to whether a defendant is pleading guilty or whether he committed the crime as charged. ${ }^{213}$ If the judge includes a terse layman's description of the offense charged, however, and the accused acknowledges such conduct, a sufficient factual basis is established, according to several jurisdictions. ${ }^{214}$ Elsewhere this practice has been disparaged as inadequate. ${ }^{215}$

Although the accused is typically interrogated by the judge, some courts allow the defense attorney or the prosecutor to conduct the questioning.218 The testimony of these attorneys has also been accepted in some states as a source of the factual basis, provided the defendant is present. ${ }^{217}$ A prosecutor's testimony usually consists.

211 See, e.g., Kendrick v. State, 308 So. 2d 152 (Fla. Dist. Ct. App. 1975), rev'd on other grounds, 336 So. $2 \mathrm{~d} 353$ (Fla. 1976). Widener v. State, $210 \mathrm{Kan}$. 234, 499 P.2d 1123 (1972); People v. Nicholson, 395 Mich. 96, 235 N.W.2d 132 (1975), cert. denied, 97 S. Ct. 1142 (1977); State v. LeGear, 187 Neb. 763, 193 N.W.2d 763 (1972); Commonwealth v. Nelson, 455 Pa. 461, 317 A.2d 228 (1974).

212 See W. Bnigham \& B. Moore, How to Intenview (4th rev. ed. 1959); Burtt \& Gaskill, Suggestibility and the Form of the Question, $16 \mathrm{~J}$. Applned Psych. 358 (1932); Gardner, The Perception and Memory of Witnesses, 18 ConNELL L.Q. 391, 402-05 (1933). But see Marshall, Marquis \& Oskamp, Effects of Kind of Question and Atmosphere of Interrogation on Accuracy and Completeness of Testimony, 84 HaRv. L. Rev. 1620 (1971).

213 E.g., State v. Durham, 108 Ariz. 327, 498 P.2d 149 (1972); Ryan v. Iowa State Penitentiary, 218 N.W.2d 616 (Iowa 1974); Cote v. State, 286 A.2d 868 (Me. 1972); People v. Serrano, I5 N.Y.2d 304, 206 N.E.2d 330, 258 N.Y.S.2d 386 (1965).

214 Ray v. Rose, 373 F. Supp. 687 (M.D. Tenn. 1973), rev'd on other grounds, 491 F.2d 285 (6th Cir.), cert. denied, 417 U.S. 936 (1974); State v. Campbell, 107 Ariz. 348, 488 P.2d 968 (1971); Widener v. State, 210 Kan. 234, 499 P.2d 1123 (1972).

215 E.g., State v. Durham, 108 Ariz. 327, 498 P.2d 149, 151 (1972).

216 E.g., State v. Irving, 299 Minn. 211, 217 N.W.2d 197 (1974); Commonwealth v. Ingram, $455 \mathrm{~Pa}$. 198, 316 A.2d 77 (1974). Contra, State v. Sisco, 169 N.W.2d 542 (Iowa 1969).

217 E.g., Church v. State, 299 So. $2 d 649$ (Fla. Dist. Ct. App. 1974); People v. Bowers, 47 Ill. 2d 585, 268 N.E.2d 13 (1971); Morgan v. State, 287 A.2d 592 (Me. 1972); People v. Williams, 386 Mich. 277, 192 N.W.2d 466 (1971); Matthews v. State, 501 S.W.2d 44 (Mo. 1973). But cf. State v. LeGear, 187 Neb. 763, 193 N.W.2d 763 (1972) (dictum) (reliance upon defense counsel as a method to determine the accuracy of a guilty plea has been disapproved). 
of a summary of the evidence he expects to present at trial. This method of establishing a guilty plea's accuracy has been limited at times, however, by requirements that a prosecutor supply concrete facts rather than merely assert that a factual basis exists, ${ }^{218}$ and that the truth of the evidence thus summarized be confirmed by the defendant. 219

Another source of information as to a guilty plea's factual basis is the testimony of witnesses before the judge at the plea hearing, ${ }^{220}$ through formal written statements, ${ }^{221}$ or by transcripts from grand jury ${ }^{222}$ or prelimnary hearing ${ }^{223}$ proceedings. In addition, some states allow the factual basis to be established by probation ${ }^{224}$ or presentence reports, ${ }^{225}$ charging documents,"226 or "any appropriate procedure." 227 Despite the diversity of methods for the accuracy inquiry, many states agree that it need not be conducted at the time of the plea, but may occur any time prior to sentencing. 228

\section{B. Standards}

Implicit in an accuracy requirement is a minimum standard of proof necessary for the establishment of an adequate factual basis. Few jurisdictions, however, have articulated a standard, and even fewer have interpreted one with any degree of sophistication. Be-

218 See, e.g., Ryan v. Iowa State Penitentiary, 218 N.W.2d 616 (Iowa 1974).

219 See, e.g., State v. Battelle, 110 Áriz. 436, 520 P.2d 308 (1974); Church v. State, 299 So. 2 d 649 (Fla. Dist. Ct. App. 1974).

220 See Church v. State, 299 So. $2 d 649$ (Fla. Dist. Ct. App. 1974); People v. Quick, 24 Ill. App. 3d 286, 320 N.E.2d 335 (1974); Edwards v. State, 51 Wis. $2 d$ 231, 186 N.W.2d 193 (1971).

221 See State v. DeAngelis, 256 S.C. 364, 182 S.E.2d 732 (1971).

222 See State v. Dixon, 111 Ariz. 92, 523 P.2d 789 (1974); Young v. Brewer, 190 N.W.2d 434 (Iowa 1971).

223 See State v. Durham, 108 Ariz. 327, 498 P.2d 149 (1972); People v. Chilton, 394 Mich. 34, 228 N.W.2d (1975); Morones v. State, 61 Wis. 2d 544, 213 N.W.2d 31 (1973) (preliminary hearing transcript and other records sufficient only if parties so stipulate).

224 See State v. Miller, 15 Ariz. App. 327, 488 P.2d 683 (1971); People v' Canino, 181 Colo. 207, 508 P.2d 1273 (1973).

225 See State v. Williker, 107 Ariz. 611, 491 P.2d 465 (1971); People v. Alvarez, 181 Colo. 213, 508 P.2d 1267 (1973); People v. Price, 9 Ill. App. 3d 693, 292 N.E.2d 752 (1973); State v. LeGear, 187 Neb. 763, 193 N.W.2d 763 (1972) (dictum).

226 See State v. Anderson, 270 Minn. 411, 134 N.W.2d 12 (1965); People v. LaPorte, 342 N.Y.S.2d 739, 41 App. Div. 2d (1973).

227 See People v. Price, 9 Ill. App. 3d 693, 292 N.E.2d 752 (1973); Cote v. State, 286 A.2d 868 (Me. 1972); State v. Armstrong, 263 S.C. 594, 211 S.E.2d 889 (1975).

228 See State v. Williker, 107 Ariz. 611, 491 P.2d 465 (1971); Mower v. State, 308 So. $2 d 586$ (Fla. Dist. Ct. App. 1975); People v. Warship, 59 Ill. 2d 125, 319 N.E.2d 507 (1974); State v. Watts, 225 N.W.2d 143 (Iowa 1975); Morgan v. State, 287 A.2d 592 (Me. 1972). 
cause neither the Supreme Court, ${ }^{229}$ federal rule $11,{ }^{230}$ nor the ABA Plea Standards ${ }^{231}$ offer any real guidance on the standard of proof required, lower federal and state courts have been left to formulate their own standards.

\section{Federal Courts}

A federal court standard of proof for factual basis is virtually nonexistent. The subjectivity inherent in rule 11, which merely states that a court must satisfy itself that a factual basis exists, ${ }^{232}$ and the deference given to a trial court's discretion in accepting or rejecting pleas have resulted in an "I-know-it-when-I-see-it" approach to the adequacy of the plea's factual basis. This subjective test led one observer to comment that

[t]here should be no room, under the final version of the rule, for collateral attack by a prisoner who contends that in fact there was no factual basis for his plea, unless uncontradicted facts disclosed by the record unequivocally demonstrate that the acts committed do not constitute the offense charged in the indictment or information. ${ }^{233}$

Linked to this subjective test is a district court's wide discretion whether to accept or reject guilty pleas. Although a judge cannot accept a guilty plea lacking any factual basis, rule 11 gives a court the discretion to reject a tendered guilty plea even if a factual basis does exist. ${ }^{234}$ A court's substantial leeway in this regard was described by the Eighth Circuit as "the greatest discretion because of the need for assurance that a guilty plea proceeding be completely safeguarded to protect the unknowing defendant." ${ }^{235}$

229 Neither Alford nor McCarthy offer any direct guidance on the issue of the standard of proof; Alford does refer, however, to the ambiguous standard of a "strong" factual basis. 400 U.S. at 38.

230 The Advisory Committee Notes speak only to methods, not standards. See 62 F.R.D. 271, 286 (1974).

231 The A.B.A. left the standard to the discretion of the judge. ABA PLEA STANDARDS, supta note 2, at 33.

232 See note 5 supra.

233 I C. Wright, Federal Practice and Procedure $\$ 174$ (1969) (footnotes omitted).

284 See Lynch v. Overholser, 369 U.S. 705 (1962) (no absolute right to have plea accepted); United States v. Gallington, 488 F.2d 637 (8th Cir. 1973), cert. denied, 416 U.S. 907 (1974).

235 United States v. Bettelyoun, 503 F.2d 1333, 1337 (8th Cir. 1974). 
The courts of appeals regularly defer to a trial judge's exercise of discretion unless it is clearly erroneous. ${ }^{238}$ As a result of such subjectivity, discretion, and deference, a defendant challenging the disposition of his guilty plea is relegated to focusing on the methods employed by the trial court rather than upon the sufficiency of the evidence. ${ }^{237}$

For analytical purposes, guilty pleas can be separated into equivocal and unequivocal pleas. Unequivocal pleas are those in which a defendant admits his involvement in the crime and expresses that, to the extent of his knowledge, he is guilty. Equivocal pleas are more troubling. Although the defendant is pleading guilty, what is said (or perhaps what is not said) during the plea procedure implies that the defendant may be legally innocent. ${ }^{238}$ When a trial judge is confronted with an unequivocal plea, his discretion is virtually unquestionable. ${ }^{239}$ As long as the judge employs a proper method to establish the factual basis, the only remaining question is whether the judge is subjectively satisfied that a factual basis exists. The equivocal guilty plea, on the other hand, has been a subject of controversy and a frequent basis for collateral attack. Cases involving equivocal guilty pleas arise in two distinct contexts. In one a defendant whose plea was accepted argues on appeal that it should have been rejected. In the other, the plea was rejected because it lacked a factual basis, and the defendant argues on appeal that it should have been accepted. Because rule 11 only requires that a court must be satisfied that a factual basis exists before accepting a guilty plea, the rejection of an equivocal plea falls in the vast area of district court discretion that is virtually unreviewable.

236 See United States v. Komitor, 392 F.2d 520, 521 (2d Cir.), cert. denied, 393 U.S. 827 (1968); United States v. Giuliano, 348 F.2d 217, 221 (2d Cir. 1965); United States v. Hughes, 325 F.2d 789, 792 (2d Cir.), cert. denied, 377 U.S. 907 (1964).

237 The difficulty in separating the methods used to determine factual basis from the standard of proof is illustrated by this quotation from United States v. Cody, 438 F.2d 287 (8th Cir. 1971): "The government's argument that this was fulfilled by the prosecutor reading from the indictment in the presence of the defendant falls far short of demonstrating any factual basis for the defendant's plea." Id. 289. The court decides that a minimum standard of proof had not been met, but the route to that determination depends upon the inadequacy of the methods used. Because the standard of proof for unequivocal pleas is usually subjective, the sufficiency of the evidence turns on the methods used rather than on the evidentiary standards.

238 See text accompanying notes 67-72 supra.

239 In only one federal case has the discretion of a trial court been overturned on appeal when the plea was unequivocal. See United States v. Ammidown, 497 F.2d 615 (D.C. Cir. 1973). The abuse of discretion in Ammidown was unrelated to the standard of proof required. 
In North Carolina v. Alford, ${ }^{240}$ the Supreme Court found no constitutional barriers to the acceptance of equivocal pleas if the factual basis was "strong" and the defendant voluntarily and intelligently chose to plead. The Alford opinion is, however, very limited in its effect on the federal court system, although the approach of several circuits toward equivocal pleas has been somewhat altered. ${ }^{241}$ Because the rejection of the guilty plea is strictly a discretionary matter, Alford has little impact when trial judges do not wish to accept an equivocal plea, regardless of the strength of the evidence against the defendant. Even the Supreme Court has added its imprimatur to the proposition that a criminal defendant has no absolute right to have his guilty plea accepted. ${ }^{242}$

Although some courts consider the rejection of equivocal pleas purely discretionary, ${ }^{243}$ others approach equivocal pleas by focusing on the voluntariness of the plea and attaching greater importance to the wishes of the defendant. 244 Still others suggest that the rejection of such pleas constitutes an abuse of discretion if there is ample evidence of guilt. ${ }^{245}$ Between these extremes lie the Alford opinion, which removes the constitutional barriers from acceptance of such pleas without compelling their acceptance, and the "public interest" approach, under which the judge's decision to accept or reject a plea turns on policy considerations. ${ }^{246}$

240400 U.S. 25 (1970).

241 Prior to Alford, the Third Circuit indicated that the acceptance of an equivocal guilty plea might constitute a denial of due process. United States ex rel. Metz v. Maroney, 404 F.2d 233 (3d Cir. 1968), cert. denied, 394 U.S. 949 (1969). Following Alford, however, the Third Circuit held in United States v. Jerry, 487 F.2d 600 (3d Cir. 1973), that equivocal guilty pleas supported by a strong factual basis in the record could be accepted.

Likewise, the Fifth Circuit in Hulsey v. United States, 369 F.2d 284, 287 (5th Cir. 1966), required an "unqualified admission of the offense charged" before a guilty plea could be accepted. Although this inflexible rule against accepting any equivocal plea was modified after Alford, the Fifth Circuit remains dissatisfied with the acceptance of equivocal pleas. See United States v. Davis, 493 F.2d 502 (5th Cir. 1974).

242 See Lynch v. Overholser, 369 U.S. 705, 719 (1962).

243 See United States v. Melendrez-Salas, 466 F.2d 861 (9th Cir. 1972).

244 See United States v. Martinez, 486 F.2d 15 (5th Cir. 1973) (rejection of equivocal guilty plea only with good reason); United States v. Bednarski, 445 F.2d 364 (1st Cir. 1971) (court must seriously consider acceptance of tendered plea); McCoy v. United States, 363 F.2d 306 (D.C. Cir. 1966) (equivocal guilty plea should not be rejected without good reason).

245 Only one court has adopted this absolute standard. In United States v. Gaskins, 485 F.2d 1046 (D.C. Cir. 1973), the D.C. Circuit stated: "It is an abuse of discretion to refuse a guilty plea solely because the defendant does not admit the alleged facts of the crime." Id. 1048.

246 See United States v. Ammidown, 497 F.2d 615 (D.C. Cir. 1973); Proposed Amendments to Federal Rules of Criminal Procedure for the United States District Courts, 62 F.R.D. 271, 286 (1974). 
When federal courts do accept equivocal guilty pleas, they have not construed Alford's vague requirement of a "strong" factual basis to require proof of the accused's guilt beyond a reasonable doubt. Several circuits have stated this conclusion explicitly, 247 whereas others have implicitly ruled that less than a trial standard for conviction will suffice. ${ }^{248}$ The District of Columbia Circuit, for example, articulated the standard as "a high probability of conviction.".249 This approach reflects a significant change of focus. Rather than being satisfied with a discretionary standard for accepting the plea, this approach looks beyond the plea bargaining process to project the probability of guilt if the defendant were to stand trial. The application of this test has generated some confusion, though. ${ }^{250}$

\section{State Courts}

Although several of the states with factual basis requirements have set standards of proof for both equivocal and unequivocal pleas, the paucity of guidance on this issue has resulted in a lack of uniformity. The standards for unequivocal pleas vary widely from each other and from the standard for conviction at trial. These standards include 1) guilt beyond a reasonable doubt; ${ }^{251}$ 2) might have been convicted at trial; ${ }^{252} 3$ ) a basis for reasonably concluding that the defendant actually committed the crime; ${ }^{253}$ and 4) not unreasonable to conclude guilt. ${ }^{254}$

A standard of proof which is less than that required to support conviction at trial and which is not normally used in the criminal justice system is difficult to articulate. ${ }^{255}$ Consequently, some juris-

247 See, e.g., Clicque v. United States, 514 F.2d 923 (5th Cir. 1975); United States v. Webb, 433 F.2d 400 (Ist Cir. 1970), cert. denied, 401 U.S. 958 (1971); McCoy v. United States, 363 F.2d 306 (D.C. Cir. 1966).

248 See, e.g., United States ex rel. Dunn v. Casscles, 494 F.2d 397 (2d Cir. 1974); Maxwell v. United States, 368 F.2d 735 (9th Cir. 1966).

249 Bruce v. United States, 379 F.2d 113, 120 n.19 (D.C. Cir. 1967).

250 The First Circuit in United States v. Webb, 433 F.2d 400 (1st Cir. 1970), cert. denied, 401 U.S. 958 (1971), held that proof beyond a reasonable doubt is not required, but then seemed to contradict itself: "It should be enough if there is sufficient evidence for a jury to conclude that he is guilty." Id. 403.

251 See ArA. Code tit. 15, $\$ 264$ (1958). This high standard may be partially explained by the fact that, except in capital cases, Alabama does not permit appellate review of plea convictions.

252 See People v. Nicholson, 395 Mich. 96, 235 N.W.2d 132 (1975), cert. denied, 97 S. Ct. 1142 (1977).

253 See People v. Hudson, 7 Ill. App. 3d 800, 288 N.E.2d 533 (1972) (standard is less than that required to convict and even less than a preponderance of the evidence); Morgan v. State, 287 A.2d 592 (Me. 1972).

254 See Clewey v. State, 288 A.2d 468 (Me. 1972).

255 People v. Nyberg, 24 Ill. App. 3d 41, 48, 320 N.E.2d 546, 551 (1974), rev'd on other grounds, 64 Ill. 2 d 210, 356 N.E.2d 80 (1976). 
dictions have refrained from fixing a single standard of proof, opting instead for a case-by-case approach. The standard may vary, for example, depending upon the defendant's demeanor, ${ }^{256}$ personal history, ${ }^{257}$ or the complexity of the charge. ${ }^{258}$ Unlike the federal courts, the states have not set special standards of proof for equivocal pleas and instead apply the Alford requirement of a "strong" factual basis to each case individually.

A corollary of the question of the standard of proof is the extent to which proof of the factual basis must appear on the record. Although some courts suggest that the better practice is for a trial. judge to recite on the record those facts relied upon in finding a factual basis, ${ }^{259}$ not all courts require this procedure. The accuracy requirement has been satisfied when the judge merely states on the record his belief that a factual basis does exist, ${ }^{260}$ or when the record itself reflects sufficient basis for the plea. ${ }^{261}$

\section{Scope}

The scope of the accuracy inquiry defines the degree to which a judge must probe a plea beyond an ostensibly adequate factual basis. Even if a prima facie factual basis exists, further inquiry may be necessary because the plea is equivocal or because the evidence presented may be inadmissible or otherwise suggest a possible legal defense.

\section{Federal Courts}

The scope of the accuracy determination has received little attention in the federal courts. Because any broadening of the inquiry's scope could be costly and time consuming, ${ }^{262}$ trial courts have been extremely reluctant to expand the factual basis procedure,

256 See State v. Campbell, 107 Ariz. 348, 488 P.2d 968 (1971).

257 See Fall v. State, 309 So. $2 d 226$ (Fla. Dist. Ct. App. 1975).

258 See Cerniglia v. United States, 230 F. Supp. 932 (N.D. IIl. 1964).

259 See Mower v. State, 308 So. $2 d 586$ (Fla. Dist. Ct. App. 1975); People v. Price, 9 Ill. App. 3d 693, 292 N.E.2d 752 (1973).

260 See People v. Doe, 6 Ml. App. 3d 799, 286 N.E.2d 645 (1972).

201 See Mower v. State, 308 So. 2d 586 (Fla. Dist. Ct. App. 1975); Morgan v. State, 287 A.2d 592 (Me. 1972).

262 An increased scope of the inquiry might, however, reduce the number of appeals because the issue of the scope of the factual basis would have been resolved on the record in the trial court. 
fearing that it might become a time-consuming, full-blown evidentiary hearing. ${ }^{203}$

The extent of the scope required varies from case to case. A problem arises as to the elements of the crime that must be demonstrated. One commentator interprets rule 11 to require "a comparison of the elements of the crime, to which the plea is offered, with the facts of the offense committed by the defendant." 264 Some courts interpret the accuracy inquiry to require proof only of obvious issues. ${ }^{265}$ Other circuits reject this rule, ${ }^{266}$ however, perhaps out of reluctance to require judges to inquire into matters that may only appear "obvious" in retrospect. ${ }^{267}$ Gonvictions based on guilty pleas have been reversed, however, because "essential" elements were not established during the factual basis inquiry, ${ }^{268}$ particularly the element of intent. ${ }^{269}$

Another problem that has received scant attention in the federal courts is the necessity for further inquiry when a potential legal defense is indicated. In general, contradictions in the evidence and suggestions of a possible defense have not constituted barriers to the

263 See United States v. Webb, 433 F.2d 400 (Ist Cir. 1970).

264 8 Moore's Federal Practice ff 11.03[3], at 1172 (2d ed. 1977) (footnote omitted).

265 See Clicque v. United States, 514 F.2d 923 (5th Cir. 1975) (for obscenity conviction, must determine whether material was constitutionally protected); United States v. Untiedt, 479 F.2d 1265 (8th Cir. 1973) (must show that goods stolen were part of interstate shipment); Gilbert v. United States, 466 F.2d 533 (5th Cir. 1972) (no factual basis for seven counts because only one illegal transportation was shown).

268 See Limon-Gonzalez v. United States, 499 F.2d 936 (5th Cir. 1974) (even though having an order form for marijuana would have been a defense to the charge of possession without paying transfer tax, judge need not determine whether defendant had such a form); United States v. Singletary, 441 F.2d 333 (5th Cir. 1971) (crime involved stealing money order over $\$ 100$, but court did not require determination of the dollar amount stolen); Semet v. United States, 422 F.2d 1269 (10th Cir. 1970) (for charge of placing a person's life in jeopardy, the court did not have to consider whether the gun involved was capable of inflicting bodily harm).

267 See Semet v. United States, 422 F.2d 1269 (10th Cir. 1970). "It taxes the imagination to conceive of a judge or lawyer who could divine every conceivable defense, mitigating circumstance, or corollary element to disclose to an accused in satisfying himself that the plea was voluntary and there was a factual basis for the plea." Id. 1272.

268 See, e.g., Rizzo v. United States, 516 F.2d 789 (2d Cir. 1975) (plea reversed because the court failed to inquire into the element of actual or threatened force or violence which is essential to the charge of extortion).

269 See United States v. Hedgecoe, 420 F.2d 458 (4th Cir. 1970); United States v. Steele, 413 F.2d 967 (2d Cir. 1969), overruled on other grounds sub nom. Manley v. United States, 432 F.2d 1241 (2d Cir. 1970). 
acceptance of a guilty plea, ${ }^{270}$ notwithstanding criticism and decisions to the contrary. ${ }^{271}$

Federal practice does not indicate the extent to which the judge should extend the scope of the accuracy inquiry to prior violations of the defendant's constitutional rights. The Eighth Circuit, however, perceived the value of such further inquiry:

[A] large number of arraignments covering a variety of crimes, may lead to an inadvertent oversight of an essential element of a particular crime. Government counsel will be more familiar with the charge and the circumstances indicating defendant's guilt. Controversy may have developed prior to entry of the plea over a confession, seizure of evidence, defendant's health and use of drugs, and many other factors which might affect defendant's plea. In short, supplemental inquiry can be very helpful to the Court in discharging its duties. ${ }^{272}$

Most opinions confronting this issue, however, have focused on voluntariness. ${ }^{273}$ The role of the accuracy determination in protecting an accused's constitutional rights remains unclear.

\section{State Courts}

The scope of the factual basis inquiry has received greater attention in state courts than in federal courts. Questions regarding the scope of the factual basis inquiry have generally arisen in cases where the facts conflict, infer a defense, or are based on evidence that would be considered inadmissible at trial.

One consideration is whether the judge must make a further inquiry when the defendant presents information to the court for factual basis purposes that conflicts with other facts before the court or with the factual basis necessary for the crime charged. Conflicting fact patterns can obviously arise when multiple methods of de-

270 United States v. Webb, 433 F.2d 400 (5th Cir. 1970), cert. denied, 401 U.S. 958 (1971) (factual basis existed though defendant claimed that his implicative statement to court contradicted previous protestations that he did not know car was stolen); Griffin v. United States, 405 F.2d 1378 (D.C. Cir. 1968) (must accept guilty plea despite inconsistent statements of accused and indications of possible self-defense claim).

271 See United States v. Ray, 431 F.2d 1177 (9th Cir. 1970) (plea rejected because defendant told probation officer that he believed he was innocent); Maxwell v. United States, 368 F.2d 735 (9th Cir. 1966) (plea of defendant who had been intoxicated and therefore could not recall crime refused).

272 United States v. Rawlins, 440 F.2d 1043, 1047 n.5 (8th Cir. 1971).

273 See, e.g., Doran v. Wilson, 369 F.2d 505 (9th Cir. 1966). 
termining the factual basis are employed, ${ }^{274}$ but may even arise when only one method is used. ${ }^{275}$ Appellate courts generally resolve these conflicts by affirming convictions without mentioning the scope of inquiry, but at least one state requires a greater scope in such circumstances. ${ }^{276}$

The scope issue arises more frequently when the defendant claims an inability to remember his actions or when facts that become known to the judge at the plea or sentence stage indicate that certain defenses may be available. Occasionally when pleas are offered a defendant claims he cannot remember committing the offense. ${ }^{277}$ Although this "failure to remember" should alert the judge to possible related defenses, such as incompetence to enter a plea, ${ }^{278}$ insanity, ${ }^{279}$ or intoxication, ${ }^{280}$ no state requires the judge to

274 E.g., Kendrick v. State, 308 So. 2 d 152 (Fla. Dist. Ct. App. 1975), rev'd, 336 So. $2 d 353$ (1976) (defendant and witnesses presented conflicting information). 275 E.g., Commonwealth v. Thomas, 450 Pa. 548, 301 A.2d 359 (1973) (at sentence, 35 days after the court accepted plea based on the defendant's statement, the defendant offered a different explanation which indicated his innocence).

276 See People v. Serrano, 15 N.Y.2d 304, 206 N.E.2d 330, 258 N.Y.S.2d 386 (1965); People v. Johnson, 33 App. Div. 2d 573, 305 N.Y.S.2d 274 (1969).

${ }^{277}$ An interesting comment has been made regarding the truth of assertions by defendants that they do not remember.

[The] assumption is that the innocent are more likely than the guilty to equivocate in pleading. But what reason is there to believe that this assumption is valid? It has been noted that emotional disturbance, which may lead to an inaccurate plea, is difficult to detect in the short space of an arraignment. And it is difficult to imagine why an emotionally disturbed person would be likely to reveal his problem by hedging his plea. A fortiori, a truly innocent, rational man who, for his own reasons, chooses to "take the rap" is least likely of all to tergiversate when pleading. Finally, there is no evidence that those guilty of only a lesser crime are more likely to equivocate. Indeed, it may well be that chief among the equivocators are the merely reluctant guilty and the dissemblers. Consequently, the asserted nexus between equivocation and inaccuracy of plea (innocence of crime charged) would appear to be problematic at best.

Note, Equivocal Guilty Pleas-Should They Be Accepted?, 75 Dick. L. REv. 366, 374-75 (1971).

True inability to remember facts of the offense might be the result of psychological blocks, mental instability, or an altered state of consciousness at the time of the act. See Young v. Brewer, 190 N.W.2d 434 (Iowa 1971) (claimed inability to recall because of intoxication and brain damage); State v. Fisher, 292 Minn. 453, 193 N.W.2d 819 (1972) (amnesia); Meeks v. State, 484 S.W.2d 167 (Mo. 1972)

(amnesia and mental defect); People v. Francabandera, 33 N.Y.2d 429, 310 N.E.2d 292, 354 N.Y.S.2d 609 (1974) (amnesia and intoxication).

278 See Pate v. Robinson, 383 U.S. 375 (1966); State v. Vane, 322 A.2d 58 (Me. 1974). See generally Note, Competence to Plead Guilty: A New Standard, 1974 DuxE L.J. 149.

279 See A. Goldstedn, The Insantty Defense (1967).

280 Voluntary or involuntary intoxication is a defense to crime when it negates the existence of an element of the crime. See Hall, Intoxication and Criminal Responsibility, 57 Harv. L. REv. 1045 (1944); Paulsen, Intoxication as a Defense to Crime, 1961 U. ILL. L.F. 1. 
increase the scope of the factual basis inquiry merely because the defendant cannot recall having committed the crime.

A different result has been reached in a closely related area when, during the accuracy inquiry, reference is explicitly made to such possible defenses as self-defense, ${ }^{281}$ intoxication, ${ }^{282}$ or lack of criminal intent. ${ }^{283}$ The discovery of such a defense is consistent with the rationale of requiring a factual basis to protect the defendant from pleading guilty when, in fact, he is not. A number of cases have been reversed because the trial judge did not inquire further when the offered plea included evidence of a possible defense. ${ }^{284}$

Even in the absence of a factual conflict or an apparent defense, the type of evidence used to establish the factual basis may be expanded. Use of statements of counsel, the presentence report, or the preliminary examination transcript in jurisdictions that allow hearsay testimony at this proceeding frequently involve testimony that would be inadmissible at trial. Two jurisdictions have indicated a concern about the use of such evidence. One court reversed a plea in a murder case because hearsay was used to establish the elements of the crime. ${ }^{285}$ Another permitted only admissible evidence to be used at a postconviction proceeding to evaluate the voluntariness determination. ${ }^{288}$

Like the federal courts, the state courts rarely elaborate those elements of the crime that must be established in the factual basis. Only a few require that the record include evidence of each element in order to establish a plea's accuracy. ${ }^{287}$ Even if only "essential" $28 s$ elements must be established, the question remains whether inferences may be used to do so. ${ }^{289}$ State courts are generally willing to

281 See, e.g., Commonwealth v. Roundtree, 440 Pa. 199, 269 A.2d 709 (1970). $28{ }^{a}$ See, e.g., State v. Battelle, 110 Ariz. 436, 520 P.2d 308 (1974); People v. Troyan, 21 Ill. App. 3d 375, 315 N.E.2d 335 (1974); Young v. Brewer, 190 N.W.2d 434 (Iowa 1971).

283 Criminal intent may be lacking altogether or intoxication may have the effect of negating any possible specific intent. See People v. Troyan, 21 11. App. 3d 375, 315 N.E.2d 335 (1974).

284 See, e.g., id.; Wayne v. State, 4 Md. App. 424, 243 A.2d 19 (1968);

People v. Stoner, 23 Mich. App. 598, 179 N.W.2d 217 (1970).

285 See People v. Nyberg, 24 Ill. App. 3d 41, 320 N.E.2d 546 (1974).

286 See Morgan v. State, 287 A.2d 592, 598 (Me. 1972).

287 See, e.g., State v. Herndon, 109 Ariz. 147, 506 P.2d 1041 (1973).

288 See People v. Hudson, 7 III. App. 3d 800, 288 N.E.2d 533 (1972) (factual basis must include evidence of intent if it is necessary element of the crime).

280 Courts may have to rely on inferences even when the accuracy inquiry involves direct interrogation of the accused if he does not answer the questions directly or is unable to respond because of loss of memory or intoxication at the time of the crime. 
draw such inferences, ${ }^{290}$ especially in establishing the element of intent. ${ }^{201}$

\section{A Proposed Standard for the Accuracy Inguiry}

The preceding discussion demonstrates the value of an accuracy inquiry in protecting an innocent defendant, the limited areas in which the criminal justice system now provides that protection, and the absence of standards and lack of uniformity where the protection is enforced. The following standard for accuracy inquiries intends to rectify these lacunae in the pleading process. ${ }^{292}$

\section{A. Proposal}

I. The accuracy of a plea of guilty or nolo contendere must be established on the record

A) by the most reliable method available. Unless determined otherwise by the judge on the record, the order of reliability is:

1) personal interrogation of the defendant

2) testimony of witnesses

3) statements of counsel, and

4) presentence or probation reports.

B) under a standard of proof equivalent to the proof necessary to defeat a motion for a directed verdict of acquittal for the crime to which the defendant pleads.

II. Despite an indication that the plea does not meet the factual basis standard, a judge may still accept a plea if, after he informs the defendant of the apparent deficiency in the factual basis, the judge establishes on the record that the defendant rationally chose to plead and concludes on the record that there is a probability of conviction at trial.

290 See People v. Nicholson, 395 Mich. 96, 235 N.W.2d 132 (1975), cert. denied, 97 S. Ct. 1142 (1977) ("A factual basis for acceptance of a plea exists if an inculpatory inference can reasonably be drawn by a jury from the facts admitted by the defendant even if an exculpatory inference could also be drawn and defendant asserts the latter is the correct inference." Id. at 130, 235 N.W.2d at 145).

291 See Thacker v. State, 313 So. 2d 426 (Fla. Dist. Ct. App. 1975); People v. Warship, 59 III. 2d 125, 319 N.E.2d 507 (1974); Clewley v. State, 288 A.2d 468 (Me. 1972); Commonwealth v. Ingram, 455 Pa. 198, 316 A.2d 77 (1974).

292 The accuracy inquiry will be only one part of the full plea colloguy. A voluntariness inquiry is also required. Boykin v. Alabama, 395 U.S. 238 (1969). 


\section{B. Commentary}

The accuracy inquiry should apply to both guilty pleas and to pleas of nolo contendere. ${ }^{293}$ Although the nolo contendere plea, by definition, ${ }^{294}$ precludes the establishment of a factual basis by personal interrogation of the defendant, there is no justification for entirely eliminating the accuracy protections for defendants who choose to use this plea. ${ }^{295}$ Although there may be clear advantages for defendants who plead nolo contendere, ${ }^{296}$ they deserve the same factual basis protection as those who plead guilty.

The accuracy determination must be made by an inquiry on the record. ${ }^{297}$ This requirement assures that the trial judge must actually evaluate the factual basis, and that the record will provide

293 The nolo contendere plea allows a court to impose a prison sentence on a defendant who does not admit his guilt. Hudson v. United States, 272 U.S. 451 (1926). The reasons why a defendant might wish to enter a plea of nolo contendere include:

(I) a reluctance on defendant's part to relate the details of a particularly sordid crime (e.g., sexual assault on a child); (2) the defendant's recollection of the facts may be unclear because he was intoxicated ... or he committed so many crimes of a like nature that he cannot differentiate one from another; and ( 3 ) because he wishes to minimize other repercussions (e.g., civil litigation).

People v. Nicholson, 395 Mich. 96, 134, 235 N.W.2d 132, 147 (1975) (citation omitted), cert. denied, 97 S. Ct. 1142 (1977).

294 Generally speaking, the plea of nolo contendere is an implied confession which admits the facts charged in the indictment and thus is similar to a plea of guilty. However, the nolo plea admits the facts for the sole purpose of the criminal prosecution. Therefore, unlike a guilty plea, it cannot be used as an admission in a subsequent civil suit.

Comment, The Plea of Nolo Contendere, 25 MD. L. Rev. 227, 227 (1965). See generally Lenvin \& Meyers, Nolo Contendere: Its Nature and Implications, 51 YALE L.J. 1255 (1942).

295 But cf. People v. Nicholson, 395 Mich. 96, 235 N.W.2d 132 (1975), cert. denied, 97 S. Ct. 1142 (1977). Michigan requires that before accepting a plea of nolo contendere, the judge must first state on the record reasons for believing that the interests of the defendant and the proper administration of justice do not require interrogation of the defendant regarding his participation in the crime.

Under the proposed standard, a judge could then examine any witnesses and counsel, or the presentence or probation reports.

296 The principal advantage to a defendant is that the plea of nolo contendere cannot be used against him as an admission of guilt in a civil action based on the same acts. Hudson v. United States, 272 U.S. 451 (1926); FED. R. Crum. P. 11(e) (6); Note, Use of the Nolo Contendere Plea in Subsequent Contexts, 44 S. CAL. L. REv. 737 (1971). This has made the plea very popular with anti-trust defendants. See 1 C. Wrighr, Federax Practice ANd Proceddre \$ 177, at 389 (1969). In addition, the plea is said to avoid the stigma of a guilty plea. United States v. American Bakeries Co., 284 F. Supp. 864, 868 (W.D. Mich. 1968); United States v. Standard Ultramarine \& Color Co., 137 F. Supp. 167, 169 (S.D.N.Y. 1955).

297 Requiring an inquiry on the record conforms to present federal law. FED. R. CRar. P. 11 ( $g$ ) requires a court to make a verbatim record of "the inquiry into the accuracy of a guilty plea." 
a basis for appellate review. ${ }^{298}$ The availability of appellate review may be as important as the trial judge's factual basis determination itself, particularly when the judge is not a lawyer or when the defendant is not represented by counsel.

A lay judge should not be excused from determining a factual basis for a plea merely because of his minimal legal qualifications. Due to the repetitive caseload in most lower courts, even lay judges, with the combination of experience and the assistance of prosecutors, should be able to determine if a factual basis is present. A requirement that the judge attempt to establish a factual basis would at least afford the defendant the protection of the record so that an appellate court could later review his conviction.

There is no indication that trial courts presently employ any criteria other than convenience in determining what method to use for establishing the factual basis of a particular plea. Courts seem to assume that a defendant can easily comprehend both the law and the facts and that all methods for establishing the factual basis are equally reliable. These assumptions ignore the Supreme Court's concern expressed in McCarthy $v$. United States that the plea bargaining process must be separated from judicial assumptions and must be based on the responses of the parties involved.299 Ignorance of the nuances of the law is hardly rare. ${ }^{300}$ Not surprisingly, a defendant often lacks the legal expertise to determine whether his

298 If the accuracy inquiry were only required to be made in open court, but not be recorded, appellate courts could not evaluate the adequacy of the factual basis. No check on the abuse of the trial judge's discretion would be available. An incomplete record leaves doubt as to the reliability of the plea procedure which was followed. Blackledge v. Allison, 97 S. Ct. I621, I634 (1977) (Powell, J., concurring). Insulation from appellate review may encourage-or at least. will not inhibit-procedural error and abuse of discretion. See S. BING \& S. Rosenfend, supra note 108, at 26-27; S. KraNTZ, supra note 111 , at 186 .

299 To the extent that the district judge thus exposes the defendant's state of mind on the record through personal interrogation, he not only facilitates his own determination of a guilty plea's voluntariness, but he also facilitates that determination in any subsequent post-conviction proceeding based upon a claim that the plea was involuntary. Both of these goals are undermined in proportion to the degree the district judge resorts to "assumptions" not based upon recorded responses to his inquiries.

394 U.S. at 467.

300 As one court has stated with some degree of understatement:

It is not unlikely that a large number of defendants are unaware of the exculpatory nuances of the law under which they believe they have committed a crime. This is especially true where individual elements of the crime are each independent pre-conditions to conviction and each necessary of proof, or where the acts themselves are measured in fine degree when assessing whether a crime has taken place.

Clicque v. United States, 514 F.2d 923, 931 (5th Cir. 1975). 
actions constitute the crime in question. ${ }^{301}$ Although some methods are more likely to illumine the true nature of a defendant's activity, others are more likely to distort it. ${ }^{302}$ Although neither McCarthy nor the notes to the federal rules express a preference among the approved methods, courts should recognize that a hierarchy of reliability exists among methods and should employ the most reliable method available in order to accomplish the goals of the inquiry. Less reliable methods should be employed only if more reliable methods have proven inadequate. ${ }^{303}$

The best method of determining the factual basis is by the direct interrogation of the defendant. Even though some lower courts have found alternatives to personal interrogation for the voluntariness inquiry, that method can best accomplish the purposes of the accuracy inquiry. These purposes cannot be accomplished by the use of printed forms, which are fraught with difficulties that would make the inquiry less accurate, more time consuming, and would not even accomplish the desired saving of courtroom time. ${ }^{304}$ This method not only allows the judge to hear the most complete and accurate description of the defendant's acts and intent, but it also assists him in determining the voluntariness of the plea. The defendant, who is usually present at the plea, ${ }^{305}$ may be questioned further if the initial statement is incomplete or raises additional problems.

In determining the factual basis, the court should first have the defendant recite the facts as he knows them; only afterward should

$30 \pi$ The defendant cannot be expected to be a lawyer. He is but one of the actors in the plea bargaining scenario. Each of the principal characters in the plea bargaining process has a specific courtroom role. The defendant brings his knowledge of the facts as they occurred; the prosecutor possesses the government's view of the facts; the judge is required to apply his unique knowledge of the law to the facts in question.

302 Distortion can result from the need to draw inferences regarding specific intent and knowledge if the defendant is not the source of the factual basis, from the use of hearsay, or from the use of sources having both an interest in the outcome and the knowledge to tailor the facts to make the plea acceptable.

303 See, e.g., People v. Nicholson, 395 Mich. 96, 134 n.3, 235 N.W.2d 132, 147 n.3, cert. denied, $97 \mathrm{~S}$. Ct. 1142 (1977) ("Direct questioning is not an absolute. ... [W] [Were the judge makes a conscientious effort to establish a factual basis for a plea of guilty by direct questioning of the defendant, omissions in the record recital of the factual basis may be established in some other manner." Id.).

304 See note 26 supra.

305 Some jurisdictions require that the defendant always enter his plea in person. See, e.g., OKLA. STat. ANN. tit. 22, $\$ 516$ (West 1969). Others allow a misdemeanor plea to be entered by counsel and do not require that the defendant be present. See, e.g., Cat. Penat Code $\$ 1429$ (West 1970); Kan. Stat. Ann. \$22-3210(6) (Supp. 1974). The federal rules permit the defendant to be absent in certain circumstances. See FED. R. CRMM. P. 43(c). Cf. Illinois v. Allen, 397 U.S. 337 (1970) (It is constitutionally permissible, under certain circumstances, to waive one's right to be present at trial). 
the court proceed with further inquiries. This method best accomplishes the intended purpose of the accuracy inquiry. ${ }^{306}$ The defendant has an opportunity to give his version of the facts and the judge gains insight into such factors as specific intent and possible defenses. A presentation by the defendant is likely to suggest questions to the judge which could serve as the starting point for an ensuing colloquy.

The use of testimony from witnesses who would testify at trial is nearly as accurate a procedure for establishing the factual basis as questioning the defendant. The major difference is the necessity of establishing by inference any intent or knowledge required for the offense. Although possibly more time consuming ${ }^{\mathbf{3 0 7}}$ and inconvenient than other methods, ${ }^{308}$ this method is characterized by a high degree of reliability. ${ }^{309}$ The judge can question the witnesses under oath, separate personal knowledge from hearsay, and inquire into facts related to specific defenses. The use of prior recorded statements of witnesses, such as a preliminary examination, evidentiary hearing, or a grand jury transcript, could also be used to establish a factual basis, despite their attendant disadvantages. ${ }^{\mathbf{3 1 0}}$ Statements by counsel or presentence reports should be used only if both of the first two methods are unavailable or have failed to provide an adequate factual basis. Either the prosecutor or defense counsel may nonetheless be a convenient source of the factual basis. They are both usually present in court; ${ }^{311}$ they may have personally investigated the case before entering into plea negotiations; they are knowledgeable about the law. The prosecutor frequently has a

306 The accuracy inquiry is much like an interview. It is generally accepted that if the interviewee is initially allowed to tell his story without interruption, the interviewer learns what the interviewee thinks is important about the incident. A. Amsterdam, B. Segal \& M. Muller, Trlad Mandal for the Defense of Crmintar Cases $\$ 83$ (1975).

307 Several witnesses may be required to establish all the elements of the charge.

308 The witnesses may have to make a special court appearance to offer support for the factual basis. If a study were done, it might be found that this method is employed only when the defendant pleads on the day scheduled for trial, and the witnesses have been summoned to court in anticipation of their having to testify at trial.

309 Besides reliability, this method can provide tangential advantages by eliciting information that might be useful for sentencing purposes, such as the severity of the injuries resulting from the assault.

310 Even though the factual basis would still come from a witness with firsthand knowledge, the judge could not make additional inquiries into questionable areas.

311 Defense counsel may not always be present, however, either because the defendant chose to represent himself, see Faretta v. California, 422 U.S. 806 (1975), or because the judge chose not to appoint a defense counsel in a case in which it was not required. See Argersinger v. Hamlin, 407 U.S. 25 (1972). 
written report which was the basis of the original charge and can simply be read into the record to establish a factual basis. ${ }^{312}$ Counsel frequently can summarize the anticipated testimony of several witnesses, thereby speeding the determination of a factual basis when numerous witnesses would otherwise be necessary.

Despite the potential time savings provided by the use of these attorneys, considerable disadvantages also ensue. If both have agreed that a plea is the desirable solution, they may employ their legal expertise to select for presentation only those facts that will tend to establish the factual basis, purposely neglecting those facts which would undermine the validity of the plea. Unscrupulous defense attorneys might persuade their clients to plead guilty when the case does not warrant such a plea. Furthermore, even though the defendant could waive the lawyer-client privilege and allow the lawyer to establish the factual basis, some might consider it unseemly that the defense attorney should supply the only evidence resulting in his client's conviction, particularly if the state's case is based on evidence that would be inadmissible at trial, such as a coerced confession. If, on the other hand, there are witnesses who are available for trial, but not for the plea, the prosecutor, not the defense attorney, should summarize their testimony. Defendants pitted against the power of the state, especially those with court-appointed attorneys, should not have their tenuous faith in the legal system further jeopardized by hearing the only evidence leading to their convictions coming from the mouths of their state-appointed lawyers. ${ }^{313}$

The principal disadvantage in the use of counsel's statements or presentence reports is that the sources of the factual basis will not have any personal knowledge of the alleged crime. In addition to the untrustworthiness of hearsay, the use of presentence reports presents an additional complication because they are not intended to prove the alleged crime in a court of law but rather to determine the proper sentence for a defendant. They are prepared by persons without legal training who may justifiably-but perhaps inaccurately -assume that the defendant is guilty because he has offered a guilty plea.

The use of charging documents to establish the factual basis should not be permitted. From an accuracy standpoint, merely having defendants acknowledge that the language in these docu-

312 This is an extremely convenient method when a nolo contendere plea is being offered.

313 Cf. People v. Losinger, 331 Mich. 490, 50 N.W.2d 137 (1951) (defendant declares that "a State attorney is worse than none." Id. at 496,50 N.W.2d at 140). 
ments describes their conduct creates many problems.' The documents frequently contain technical language and terms of art that may be indecipherable to a lay defendant.

Although the court can move down the reliability hierarchy until a sufficient factual basis is established, the number of alternative methods available probably will be fewer when the plea is a misdemeanor. Certain proceedings which generate sources for a factual basis will occur only where the original charge is a felony. ${ }^{\mathbf{3 1 4}}$

Courts which have considered the time at which the factual basis must be established agree that it need not be established when the plea is offered. Rather, it may be established at any time prior to sentencing. It might, however, cause psychological strain for thedefendant not to know if his plea has been accepted, and in rare cases it may result in damage to the defendant's case if he is ultimately required (trial-factual-basis) or desires (notice-factual-basis) to stand trial. ${ }^{315}$ It is therefore desirable that the judge conduct the accuracy inquiry as soon as possible after the plea is tendered.

The first consideration regarding the standard of proof is the charge to which the standard of proof applies. The proposal advocates that the factual basis for the defendant's plea should be evaluated in comparison to the factual basis required for the crime to which he pleaded, thus insuring that defendants who plead to negotiated charges, ${ }^{316}$ as well as those who plead to original charges, will be protected by the accuracy inquiry. Acceptance of a plea where a factual basis is shown for another crime to which the defendant is

314 Misdemeanor cases, for example, do not require grand juries or preliminary hearings; therefore, no transcripts of those proceedings are available to establish a factual basis.

315 The defense attorney may suspend investigation and preparation if the defendant indicates a desire to plead. If the plea is later rejected, some of the witnesses and evidence may be unavailable for trial.

Such failure to investigate is contrary to the ABA defense standards:

It is the duty of the lawyer to conduct a prompt investigation of the circumstances of the case and explore all avenues leading to facts relevant to guilt and degree of guilt or penalty. The investigation should always include efforts to secure information in the possession of the prosecution and law enforcement authorities. The duty to investigate exists regardless of the accused's admissions or statements to the lawyer of facts consituting guilt or his stated desire to plead guilty.

ABA Defense Standards, supra note 44, at $\$ 4.1$ (emphasis supplied).

310 The offense to which the defendant pleads need not be a lesser included offense. "[W] reiterate our conviction that the plea bargain plays a vital role in our system of criminal procedure; we would be loath to reduce its usefulness by confining it within the straightjacket of "necessarily included offenses." "People v. West, 3 Cal. 3d 595, 613, 477 P.2d 409, 421, 91 Cal. Rptr. 385, 397 (1970). The offense must be one which the defendant actually committed, however, or else no truthful factual basis can be obtained. 
not pleading ${ }^{817}$.distorts the protection policy underlying the factual basis requirement even if the factual basis is for a crime of equal or greater severity than the one charged. There is no justification for creating lingering feelings of injustice which the defendant may experience ${ }^{318}$ when his recitation of facts (even if they indicate the original crime charged was committed) would be insufficient for a guilty verdict at trial on the charge of which he will stand convicted. Nor is there justification for convicting a person of any crime merely because he admits to the commission of a crime with which he was never charged. The only way to effectuate the protective role of the accuracy inquiry is to require that the factual basis satisfy the crime to which the defendant is pleading. ${ }^{319}$

The selection of the standard of proof to be required presents a difficult problem because there are currently many different standards being used for varying purposes within the criminal justice system. ${ }^{320}$ The standard chosen for factual basis purposes could differ from other standards, however, because a defendant in this context is admitting guilt rather than contesting it as in all other proceedings. ${ }^{321}$ The protection policy does, however, suggest the utility of an established standard. If the defendant is to be protected, the factual basis should test all elements of the crime. Because a defendant may not be convicted at trial without proof of all the elements of the crime, ${ }^{322}$ the standard of proof chosen should also make it impossible to accept the defendant's guilty plea unless all the elements are established during the factual basis determination. Without proof of every element, innocence must be assumed.

317 The A.B.A. authorizes such a procedure. ABA PREA STANDARDs, supta note 2 , at $32-33$.

318 See note 39 supra.

319 A limited exception to this prophylactic rule would be the rare circumstance in which (I) the defendant is pleading to a negotiated charge; (2) the charge was selected for its preferred sentencing options; (3) the defendant could not offer a truthful factual basis to any other charge with similar sentencing provisions within the jurisdiction; and (4) the judge is unwilling to engage in sentence bargaining on the original charge to which the defendant could offer a truthful factual basis. If the judge refuses to negotiate as to the sentence imposed for a given charge, the defendant should be allowed to waive the factual basis requirement (which is required only for his protection) and plead to a charge without a factual basis.

320 See, e.g., Lego v. Twomey, 404 U.S. 477 (1972) (preponderance of evidence standard for judging voluntariness of confession); In Re Winship, 397 U.S. 358 (1970) (beyond a reasonable doubt standard for determining guilt at trial); Beck v. Ohio, 379 U.S. 89 (1964) (probable cause standard for warrantless arrests).

321 The defendant is not contesting that it was he who committed the act, but merely inquiring whether the act which he committed is a crime.

322 See Vachon v. New Hampshire, 414 U.S. 478 (1974); Thompson v. City of Louisville, 362 U.S. 199 (1960). 
Adoption of a standard of proof requiring all elements of the crime to be established will necessitate the use of inferences. Inferences can, of course, be drawn from evidence at trial; ${ }^{223}$ there is no logical reason why inferences should not be drawn at the plea. ${ }^{324}$ The defendant should, however, be informed by the judge that although the requisite knowledge or intent for the offense has not been directly proven, the judge can legally draw such inferences from the facts, and that he is prepared to do so if the defendant wishes to plead.

Even if proof of every element is required, the "beyond a reasonable doubt" standard ${ }^{325}$ need not be invoked. ${ }^{326}$ A more appropriate test for the factual basis would be the directed verdict test. ${ }^{327}$ This test focuses on establishing the elements of the crime. It enjoys the distinct advantage of currently being used in every jurisdiction. As a result, the standard would be available for immediate implementation through the interpretation of prior case law. The choice of the directed verdict standard implies that only admissible evidence may be considered for factual basis purposes. This concern for the quality of proof, in addition to concern for the amount of proof, relates to the definition of factual and legal innocence. Concern for the admissibility of the evidence ${ }^{328}$ would bene-

323 See People v. Wright, 44 Mich. App. 111, 205 N.W.2d 62 (1972).

324 People v. Nicholson, 395 Mich. 96, 235 N.W.2d 132 (1975), cert. denied, 97 S. Ct. 1142 (1977) (a judge accepting a plea is entitled to draw the same inferences that a jury might if considering the same information).

325 See In Re Winship, 397 U.S. 358 (1970).

326 There is no necessity to equalize the minimum standards for convictions by plea and by trial, see note 321 supra, although this has been cited as a reason for applying the "beyond a reasonable doubt" standard to the factual basis determination. Heverling, Judicial Review of the Guilty Plea, 7 Lncoun L. Rev. 137, 184 (1972).

327 The directed verdict test is also referred to as a motion for judgment of acquittal. See FED. R. CRDM. P. 29. A motion for directed verdict will be granted if there is insufficient evidence to support a conviction. The test of sufficiency is " whether, taking the view most favorable to the government, a reasonably-minded jury could accept the relevant evidence as adequate and sufficient to support the conclusion of the defendant's guilt beyond a reasonable doubt." " United States v. Amato, 495 F.2d 545 (5th Cir. 1974), cert. denied, 419 U.S. 1013 (1974) (quoting United States v. Jeffords, 491 F.2d 90 (5th Cir. 1974)). Despite the presence of a reasonable doubt element in the directed verdict test, the test is not as stringent as the standard for conviction at trial. At trial, the jury must weigh the evidence, decide what evidence to credit, and-based on that determination-decide if the state has proven its case beyond a reasonable doubt. In the directed verdict test, the fact finder's role as weigher of the evidence is replaced by a legal conclusion that all the evidence is to be considered in the light most favorable to the government.

328 "No prosecutor should, in connection with plea negotiations, engage in, perform, or condone any of the following:

1. Charging or threatening to charge the defendant with offenses for which the admissible evidence available to the prosecutor is insufficient to support a guilty 
fit not only the factually innocent defendant, but also the defendant who, although having committed the offense, would be acquitted at trial because of the inadmissability of the evidence. Since trialfor which the plea is a substitute-would protect this category of defendants, the plea should do so as well. If the judge concludes that although there is some evidence of every element of the charge, it is not evidence that would be admissible at trial, he should so inform the defendant under the procedures in Section II of the proposal.

Section II of the proposal is designed for the plea that does not have a sufficient factual basis. Because of the deficiency ${ }^{329}$ in the factual basis, the plea can be considered equivocal. Equivocal and unequivocal pleas represent different types of pleas and different standards should apply to each. Equivocal pleas should require a lower standard of proof and a greater scope of inquiry in order to be valid.

The unequivocal pleader admits that his conduct is factually as alleged and he is dependent upon the judge to determine whether he has commited a crime. In a sense this defendant entrusts himself to the judge's knowledge; therefore, he should have the strictest standard applied to his plea. The equivocal pleader differs in that he does not admit, but is willing to accept, the facts alleged against him. The equivocal pleader should be allowed to rely on the judge to point out reasonable defenses. If the defendant has possible defenses made known to him and then chooses to plead, this plea is sufficiently intelligent. If the plea is supported by an appropriate waiver of any infirmities and is supported by a finding of "probability of conviction," it should be accepted.

The scope of the accuracy inquiry for the equivocal plea should comport with a notice-factual-basis test that informs a defendant of deficiencies in his offered plea that suggest possible innocence without requiring the defendant to stand trial. Because the accuracy inquiry is intended to protect the defendant, he should be allowed to waive its protection and have his plea accepted after receiving notice of the possible deficiencies if he concludes that, under the circumstances, a plea is in his best interests. Whatever

verdict." National Advisory Commission on Crmmnat Justice Standards and GOALS, Courrs $\$ 3.6$ (1973).

The National Advisory Committee also recommends that a plea not be accepted if "[ $t]$ he admissible evidence is insufficient to support a guilty verdict on the offense for which the plea is offered, or a related greater offense." Standard 3.7(8) at 60 .

329 Possible sources of the deficiency could be conflicting facts, inference of a legal defense, a claimed defense, a denial of guilt, a missing element, necessity of inferring specific intent, inadmissible evidence, or a violation of a constitutional right. 
the nature of the deficiency, the defendant should be informed of the deficiency on the record and permitted to waive it and persist in. his plea. After indicating on the record that he is satisfied the defendant is pleading with knowledge that there is a possible defense, the judge may accept the plea if he concludes under the facts presented to him and indicates on the record that there is a probability of conviction..$^{330}$ The probability of conviction standard should be enforced for every equivocal plea. The trial judge's discretion necessarily inheres in this standard. The judge can use his unique knowledge not only of the law, but also of the dynamics of the trial process to determine whether the defendant's conviction is probable. ${ }^{331}$

A recurring problem might arise when judges exercise their discretion and refuse to accept a defendant's plea. Since a defendant has no absolute right to have his plea accepted even if it has a sufficient factual basis, ${ }^{332}$ a judge may reject the plea when a factual basis is insufficient. A presumption in favor of accepting the plea should be created, however, whenever there is a sufficient factual basis, or when-although there is an insufficient factual basis-the defendant waives the accuracy determination protection and the judge finds a probability of conviction at trial.

\section{Costs of AN ACGURACY INQUIRY}

An important consideration in evaluating the accuracy inquiry is its cost. The cost of employing an accuracy inquiry mainly results from the extra time judges must spend with defendants to make the inquiries, and the extra time required for trials of defendants who would have been convicted on the basis of their guilty pleas were it not for the accuracy inquiry. These time factors will, of course, translate into a dollar cost for additional judges, supporting staff, and courtroom space which must be financed if existing judges are unable to accommodate this extra time. Additional costs include those of recording all pleas, transcribing pleas which are appealed, litigating accuracy inquiry appeals, and trying or

330 In this area also the record requirement can reduce judicial abuse of discretion. Cf. United States v. Davis, 516 F.2d 574 (7th Cir. 1975) (trial judge should state his reasons for rejecting guilty plea).

331 See, e.g., United States v. Jerry, 487 F.2d 600 (3d Cir. 1973). In accepting defendant's plea, the judge reasoned: "I $I$ am taking into consideration the demeanor and appearance of Mr. Saunders, my evaluation of how he would appear as a witness before a jury. I am taking into consideration Mr. Jerry's appearance and demeanor and method of speaking and how I feel he might impress a jury." " Id. 609.

332 Lynch v. Overholser, 369 U.S. 705 (1962). 
repleading those cases that are reversed on appeal. The overall cost of providing the accuracy inquiry, however, should prove minimal. The accuracy inquiry should be a marginal time component of the full plea colloquy, requiring, in most cases, one or two minutes at most. ${ }^{333}$ This additional time will probably create only a minimal increase in the work load of felony judges. ${ }^{334}$

The only potentially major cost to the felony courts is the added expense for trials of defendants who would have pleaded guilty but for discovering through the accuracy inquiry that they may not have committed the crime. If these people are factually innocent, or learn of a possible legal defense through the accuracy inquiry, the cost of their trials must be absorbed by the judicial system. Failure to provide the accuracy inquiry and any resulting trials implies that the system is willing to deceive defendants in order to obtain pleas. Although the presence of counsel may mean that few felony defendants will learn only at the plea stage that they may be factually or legally innocent, courts should not tolerate the assumption that a defendant has been informed by counsel of his rights and possible defenses..$^{335}$

Other costs associated with adoption of the inquiry in felony pleadings are low. Because most, if not all, felony courts are courts of record, most pleas are recorded as a matter of course. Even where this is not presently the case, recording accuracy inquiries will require only a negligible expenditure because these courts are already capable of recording testimony. The cost of transcripts for appeal should also be minor because plea transcripts will usually be only a few pages in length.

Establishing an accuracy inquiry procedure, of course, creates a source of appellate litigation and the possibility of reversal of some pleas. Although appellate courts are perhaps already overburdened

333 Cf. McCarthy v. United States, 394 U.S. 459, 472 (1969) (voluntariness inquiry requires only a few minutes).

334 This conclusion is borne out by past experience with the implementation of the accuracy inquiry in federal courts. For example, during 1975, the 20 judges of the Detroit Recorder's Court took 5,907 guilty pleas. RECORDER's CourT OF THE Citry of Deirort, Micrigan, 1975 Aninual Report. Each judge heard approximately 295 pleas in 1975, which would average out to between one and two pleas a day, assuming 250 work days. Certainly each judge can find two to four extra minutes to make accuracy inquiries. In no jurisdiction where this inquiry has been instituted has the requirement ever been removed, implying favorable experience with the requirement, insignificant disruption of the jurisdiction's court system, or both.

335 Cf. Boykin v. Alabama, 395 U.S. 238 (1969) (impermissible to assume defendant has been informed of his constitutional rights). 
with litigation involving guilty pleas, ${ }^{336}$ the inquiry should not appreciably increase, and may in fact decrease, the number of appeals taken. Reversal on appeal will create an additional cost resulting from re-pleading or conducting a trial; it does not mean, however, that legally guilty people will be allowed to escape the criminal sanction. The defendant's case will not be dismissed at the appellate level. The prosecution will have the opportunity to try the defendant or obtain a new plea. Furthermore, once trial judges become familiar with the accuracy inquiry procedure, very few pleas should require reversal.

The cost of implementing the accuracy inquiry for misdemeanors is more difficult to estimate; a greater expenditure might be required than in felony cases. In all but the major metropolitan districts, the present staff of judges should be able to accommodate the extra time per case required for the improved plea procedure, as well as the time for an occasionally resulting trial. ${ }^{337}$ But even in the high case volume courts, despite the horror stories of assemblyline type dispositions, ${ }^{338}$ the inquiry should only require a maximum of one to two additional judge-hours per day. ${ }^{339}$ At worst, some of these courts may require one or two new judges and support personnel if it is determined that the existing judges cannot manage the docket.

One real expense for the lower courts would be incurred by making a record of the plea in courts that are not presently courts of record. ${ }^{340}$ This could be done at minimal expense by using cas-

336 From 1965 to 1967 , approximately $25 \%$ of all criminal appeals to the Michigan Court of Appeals involved guilty pleas. Comment, Profile of a Guilty Plea: A Proposed Trial Court Procedure for Accepting Guilty Pleas, 17 WAyne L. REv. 1195,1211 n.90 (1971). The average guilty plea appeal in Illinois requires between 12 and 20 hours of research, brief and opinion writing, and argument. Comment, Guilty Pleas in Illinois, 24 DePaUr L. Rev. 42, 91 (1974).

337 It might be assumed that an accuracy inquiry in the lower courts would lead to an increased number of trials because the inquiry would enlighten the legally ignorant, uncounseled defendant, or inform the poorly counseled defendant. Improvement in lower court due process, however, does not automatically translate into more trials. After Argersinger v. Hamlin, 407 U.S. 25 (1972), and the resulting increase in the appointment of counsel for misdemeanants, total trials decreased in some jurisdictions. Ingraham, The Impact of Argersinger-One Year Later, 8 LAW \& Soc'x REv. 615, 623-25 (1974).

338 See, e.g., Foote, Vagrancy-Type Law and Its Administration, 104 U. PA. L. Rev. 603, 605 (1956) (court heard 55 cases in 15 minutes); Mileski, supra note 108, at 479 ( $72 \%$ of cases in lower courts are heard in one minute or less).

339 Most jurisdictions have no more than 60 cases per day, only 30 of which are pleas. At one to two additional minutes per plea, the inquiry will require one to one and a half additional hours per day.

340 See S. KraNiz, supra note 111, at 185-86. 
sette electronic recording devices. ${ }^{341}$ The plea, which need only be transcribed in those rare instances where the defendant appeals, would normally be short, and therefore inexpensive to transcribe. The recorded plea proceedings could even be heard by the reviewing court without transcription.

Furthermore, it should be recognized that very few misdemeanor convictions are appealed. ${ }^{342}$ The vast majority of those appeals are likely to be from trials rather than pleas because the defendant who made an initial decision not to contest guilt is less likely later to contest his conviction. In addition, the trial de novo procedures used for misdemeanors in many states ${ }^{343}$ obviate the need to appeal a conviction for the defendant who later regrets his earlier plea.

\section{Conclusion}

A survey of current procedures for the acceptance of guilty pleas demonstrates the necessity of an accuracy inquiry for all defendants, regardless of the degree of crime with which they are charged. Under present procedures in many jurisdictions, a judge can accept a plea upon hearing that the defendant wishes to plead guilty; the possibility is great of convicting defendants who are factually innocent. No factual or legal rationale favors the retention of a procedure that can so easily result in such an unjust outcome. An effective accuracy inquiry is the simplest and most reliable method of instituting a desired change.

The benefit of applying felony plea practices to misdemeanor pleas is substantial. Those charged with misdemeanors will be protected from improper surrender of their rights. ${ }^{344}$ Courts will be protected from accusations of improperly convicting the innocent and the integrity of the courts will be enhanced. Society in general will benefit from the greater productivity of innocent people who would have been convicted but for the new procedure. These people will have a better opportunity for additional future employ-

341 ABA Standards Relating to Truax Counts $\$ 2.42$ (Tent. Draft 1975): "[A] relatively simple audio reporting system may suffice for a docket of short cases where appellate review is infrequent."

342 Note 108 supra.

343 See generally North v. Russell, 427 U.S. 328 (1976); RoJgh JusricE, supra note 33 , at xviii.

344 Admittedly, no one knows how many innocent people are convicted of crimes either by plea or trial. However, one study has shown that pressure on defendants to plead guilty in the federal courts has induced a high rate of conviction by pleas in cases in which no conviction would have been obtained if there had been a trial. Finkelstein, A Statistical Analysis of Guilty Plea Practices in the Federal Cousts, 89 Harv. L. Rev. 293, 295 (1975). 
ment because they.will have no criminal record, and they will be less likely to commit future criminal acts because of feelings of alienation generated by prior wrongful convictions.

Opposition to the accuracy inquiry is based on arguments of convenience and cost. The meager time expenditure required for the accuracy inquiry, however, would be more than offset by the increased respect for and quality of justice in criminal courts. To the extent that opposition to the accuracy inquiry is founded on fears that defendants who learn of their possible innocence or of possible defenses may choose to exercise their rights and put the state to the test of proving its charges, the admonition of $\mathrm{Mr}$. Justice Goldberg in Escobedo.v. Illinois ${ }^{345}$ is directly on point: "no system of criminal justice can, or should, survive if it comes to depend for its continued effectiveness on the citizens' abdication through unawareness of their constitutional rights." 346

345378 U.S. 478 (1964).

346 Id. 490. 